\title{
Overeducation at the start of the career - stepping stone or trap?
}

\author{
Stijn Baert \\ Bart Cockx \\ Dieter Verhaest
}

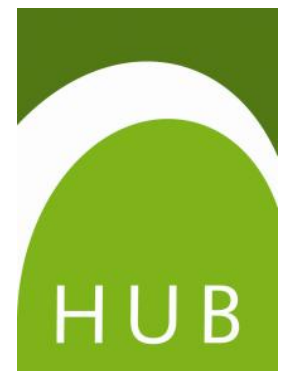




\title{
Overeducation at the start of the career - stepping stone or trap?*
}

May 2012

\author{
Stijn Baert ${ }^{\mathrm{a}}$ - Ghent University \\ Bart Cockx ${ }^{b}$ - Ghent University, Université catholique de Louvain, CESIfo and IZA \\ Dieter Verhaest $^{\mathrm{c}}$ - Hogeschool-Universiteit Brussel and Ghent University
}

This study investigates whether young unemployed graduates who accept a job below their level of education accelerate or delay the transition into a job that matches their level of education. We adopt the Timing of Events approach to identify this dynamic treatment effect using monthly calendar data from a representative sample of Flemish (Belgian) youth who started searching for a job right after leaving formal education. We find that overeducation is a trap. This trap is especially important early in the unemployment spell. Our results are robust across various specifications and for two overeducation measures.

JEL classification: C21, C41, 121, J24, J64

Keywords: overqualification, underemployment, school-to-work transitions, duration analysis, dynamic treatment

\footnotetext{
*We thank Jim Allen, Kristof De Witte, Matteo Duiella, Freddy Heylen, Francesco Pastore, Matteo Picchio, Giuseppe Rose, Peter Sloane, Walter Van Trier and the seminar participants at Ghent University, Université catholique de Louvain, VU University Amsterdam, the European Network on Transitions in Youth Workshop 2011, the Day of the Scientific Economic Research of the Flemish Society of Economics 2011, the Workshop on Overeducation in Naples and the Spring Meeting of Young Economists 2012 for their insightful comments and suggestions, which have helped to improve this study considerably. In addition, we are grateful to the Steunpunt SSL of the Flemish government for the used SONAR data. The authors assume the sole scientific responsibility of the present work.

${ }^{a}$ Study Hive for Economic Research and Public Policy Analysis (SHERPPA) - Ghent University, Tweekerkenstraat 2, B-9000 Gent, Belgium, Stijn.Baert@UGent.be

${ }^{b}$ Study Hive for Economic Research and Public Policy Analysis (SHERPPA) - Ghent University, Tweekerkenstraat 2, B-9000 Gent, Belgium, Bart.Cockx@UGent.be

${ }^{c}$ Human Relations Research Group (HRRG) - HUBrussel, Warmoesberg 26, B-1000 Brussels, Belgium, Dieter.Verhaest@HUBrussel.be
} 


\section{Introduction}

Numerous studies have shown that many young workers are overeducated at the start of their careers (see, e.g., Battu et al., 1999; Dolton and Vignoles, 2000). A worker is considered to be overeducated if her/his education is higher than the level that is typically required to perform adequately. This phenomenon suggests a less-than-optimal allocation of graduates over jobs and is potentially costly for society (Groot and Maassen van den Brink, 2000; McGuinness, 2006). For overeducated workers, this translates in lower earnings (Hartog, 2000) and lower job satisfaction (see, e.g., Tsang, 1987; Allen and van der Velden, 2001). Therefore, one might wonder why young job seekers actually accept jobs with requirements below their educational attainment. One potential answer is that this is the shortest pathway to a job that matches the attained educational level. This stepping stone hypothesis has been formulated most clearly by Sicherman and Galor (1990). According to their career mobility theory, overeducation is an investment in work experience which enhances promotion opportunities to higher level positions inside or outside the firm. In addition, by taking these positions, workers avoid unemployment scarring (see, e.g., Arulampalam, 2001), resulting from negative signalling, skill depreciation or psychological discouragement. However, overeducation might just as well retard the transition to an adequate job. Job specific human capital investments may lock workers into bad positions (Pissarides, 1994). Further, the sources underlying unemployment scarring may equally apply to overeducation. According to McCormick (1990), overeducation even acts as a stronger negative signal to employers than unemployment and de Grip et al. (2008) show that overeducation also results in cognitive decline. Moreover, Verhaest and Omey (2009) find that the negative association between overeducation and job satisfaction declines over time, suggesting some habituation. Finally, while job search models show that it may be optimal to accept a lower position and to pursue on-the-job search (Dolado et al., 2009), it is doubtful whether the same search intensity can be maintained.

Several empirical studies have already provided interesting insights into this debate by investigating the mobility behaviour of overeducated workers. Sicherman (1991) and Robst (1995), for instance, find for the US that overeducated workers are more likely to move to occupations with higher human capital requirements than adequately educated workers with similar educational backgrounds. This is consistent with the career mobility thesis. In addition, Rubb (2003) reports a yearly transition rate from overeducation to adequate employment of about $20 \%$, suggesting that overeducation is a temporary problem for most US workers. However, a number of studies for other countries challenge this conclusion. Battu et al. (1999) find that the match between the educational degree 
and the job requirements remains fairly stable around $60 \% 1,6$ and 11 years after graduation for two cohorts who graduated from higher education in the UK. Dolton and Vignoles (2000) arrive at similar conclusions. Bauer (2002) finds, using the German GSOEP data from 1984 to 1998, that relatively few employees change their mismatch status. This is confirmed by Büchel and Mertens (2004) who report that overeducation results in less upward occupational mobility and less wage growth in the German labour market. This is especially for young workers with low-quality education (PollmannSchult and Büchel, 2004). More recently, Verhaest and van der Velden (In press) studied the persistence of overeducation in 14 countries. They find substantial heterogeneity in this persistence both across countries and within countries according to the quality and orientation of their human capital. Finally, Mavromaras and McGuinness (In press) estimate a dynamic random effects probit model allowing for correlated unobserved heterogeneity on Australian data. They find substantial state dependence in overskilling ${ }^{1}$ for workers with a high educational degree, but none for workers with vocational education. Based on a similar model and consistent with the aforementioned findings, Mavromaras et al. (2010) report that neither overeducation nor overskilling has any significant effect on job mobility of female university graduates in Australia. By contrast, overeducation, especially in combination with overskilling, positively affects (voluntary) quits, but not (involuntary) layoffs of male graduates. Whether this leads to more upward occupational mobility remains an open question, however.

From this overview of the literature we conclude that evidence for the career mobility theory is mixed. Moreover, most researches just study the persistence of overeducation. However, even if overeducation is persistent, this does not reject the hypothesis that overeducation is a stepping stone to an adequate job. After all, an individual who does not accept a job for which (s)he is overeducated may remain unemployed (and therefore without adequate job) even longer than when (s)he accepts such a job. This article studies the stepping stone hypothesis. In other words, we investigate which strategy unemployed graduates should follow if they aim at speeding up the transition to a job that matches their educational qualifications. Should they, to avoid getting trapped into overeducation, (i) only accept adequate jobs that match their educational qualifications? Or, do they have an interest in (ii) accepting jobs for which they are overeducated, because these jobs are springboards that speed up the transition to an adequate job?

Our analysis also innovates in the overeducation literature from a methodological point of view. As pointed out by Leuven and Oosterbeek (2011), many studies on overeducation and its consequences

\footnotetext{
${ }^{1}$ Overskilling is a situation whereby an individual has more skills and knowledge than those utilized in the job (cf. Allen and van der Velden, 2001; Green and McIntosh, 2007).
} 
fail to account for possible non-random selection into overeducation. ${ }^{2}$ For instance, overeducated workers may be less able than adequately educated workers. If so, the comparison of the outcomes between adequately qualified and overeducated workers may partly reflect this ability difference and is therefore not causal. To solve this selection problem, we apply the Timing of Events approach as developed by Abbring and van den Berg (2003). To identify the selection from the treatment effect, this method exploits that unobserved time-constant individual determinants of the transition to an adequate job affect this transition throughout the period that one is searching for an adequate job whereas the treatment (transition into overeducation) may only influence this transition as from the moment at which the treatment occurs. The selection effect can therefore be identified from the pre-treatment data if the treatment is not anticipated and the timing of the treatment is random, even without any exclusion restrictions.

The analysis is based on a retrospective survey of a representative sample of two birth cohorts, born in 1978 and 1980 and living in Flanders, the Dutch-speaking region in the North of Belgium. From this sample we retain male unemployed youth who started searching for a job right after graduating from formal education. An advantage of analysing data right after graduation is that there is a closer connection between the concept of overeducation and overskilling, since individuals have not yet acquired any skills through experience on-the-job. Moreover, the unusual richness of the database sustains the credibility of our findings. On the one hand, it contains detailed information on the timing of labour market transitions: starting dates of job search, transitions from unemployment to employment and even job-to-job and position changes within a same firm. This is crucial for the application of the Timing of Events method and also to capture career mobility even if it occurs within the firm, ensuring that our study cannot be criticized on the grounds of underestimating career mobility. On the other hand, both educational attainment and the job requirements are precisely registered, which allows constructing two measures of overeducation, one based on a job analysis approach and another on a modified self-assessment method. Since the educational requirement according to the latter method is nearly universally higher than the latter, the likelihood that the modified self-assessment method identifies "apparent" overschooling is reduced. This matters, since Chevalier (2003) argues that genuinely overschooled workers are more likely to move to a higher level job than those who are apparently overschooled. Consequently, since our findings are not sensitive to the choice of these measures, we are quite confident that they are not driven by incorrect measurement of the educational requirements.

\footnotetext{
${ }^{2}$ The aforementioned articles of Mavromaras and McGuinness (In press) and Mavromaras et al. (2010) are rare exceptions with respect to the literature on the job mobility of overeducated workers.
} 
The article is organized as follows. In the next section we describe the dataset in further detail and provide some selected descriptive statistics. Section 3 discusses the econometric framework. Section 4 contains and discusses the estimation results. Section 5 concludes.

\section{Data and descriptive statistics}

\subsection{The sample of analysis}

Our analysis is based on data from a representative sample of two cohorts (birth years 1978 and 1980) of the SONAR survey conducted when respondents were 23 years old. Each cohort contains about 3000 individuals. These data are supplemented with data from two follow-up surveys, completed at age 26 for the 1978 cohort (response rate of 69\%) and at age 29 for the 1980 cohort (response rate of 64\%). Detailed information regarding the sampling procedures and general summary statistics can be found in SONAR (2003) and SONAR (2005).

The SONAR data contain detailed information regarding school and labour market careers, which make them very suitable for our analysis. The level of acquired educational attainment is measured at the moment that the youngster reports to have left formal education for the first time. The labour market history is registered on a monthly basis. Each month is assigned either to a working or to a non-working status, depending on the status in which one spends most of the time. Further, if employed, both job-to-job transitions and position changes within a job are recorded. Part-time jobs held during vocational education, student and vacation jobs are defined to be part of the educational career.

The analysis targets workers who are unemployed right after graduation. We therefore select individuals from the first moment that they report to have started searching for a job since graduation. ${ }^{3}$ Furthermore, we only consider men because their labour market decisions are less affected by fertility considerations. Finally, we exclude men who did not attain a degree of lower secondary education, because below this level of education no one is overeducated by definition.

\footnotetext{
${ }^{3}$ We do not retain individuals who started searching for jobs during their studies, since for these individuals we cannot identify the moment at which they found a job (if this occurs before graduation). Without information on this moment the Timing of Events approach cannot be implemented.
} 
After eliminating 114 observations for which explanatory variables are missing, the final dataset contains 1434 individuals.

\subsection{Measures of overeducation}

In the main analysis we define overeducation according to a job analysis approach. Each position in the SONAR data has been coded following the Standard Occupation Classification of Statistics Netherlands (CBS, 2001). This classification groups jobs according to a set of tasks to be executed and assigns to each occupation an educational level that is the most appropriate. The following five functional levels are considered: less than lower secondary, lower secondary, higher secondary, lower tertiary and higher tertiary education. Hence, an individual is considered to be overeducated if the functional level of her/his job exceeds her/his attained educational level. Those with a functional level above their educational level, the so-called undereducated, are considered to be adequately educated in this article. Considering this - small - group as a separate category would further complicate the analysis. Moreover, undereducated individuals generally earn at least as much and are at least as satisfied with their jobs as adequately educated workers (Hartog, 2000; Verhaest and Omey, 2009). Hence, this justifies pooling them with the adequately educated.

Apart from job analysis, several other measurement approaches, for instance based on selfassessments, have been applied in the literature (see Leuven and Oosterbeek, 2011, for an overview). As any method, job analysis has some disadvantages. One often formulated criticism is that, within a particular occupation, there may be substantial heterogeneity in the tasks to be executed. However, since the SBC-classification is rather built upon tasks to be executed than on occupational titles, this problem should be less severe for our measure. Furthermore, in a number of validation studies (van der Meer, 2006; Verhaest and Omey, 2010), the CBS measure performed at least equally well as other measures. Nevertheless, we also execute a sensitivity analysis relying on a modified self-assessment approach. The SONAR survey included the following survey question regarding the first job: "What is (was), according to your own opinion, the most appropriate educational level to execute your job?" As this question was not included for subsequent jobs, we adopted the following construction procedure for our alternative measure. First, relying on this information on first jobs, we computed the median subjectively assessed required level within each 
occupation. ${ }^{4}$ Second, we assessed both for the first job and for later jobs whether someone was overeducated or not by comparing her/his educational level with this computed median of the subjectively required level.

According to the job analysis method within the retained sample $59 \%$ of the first jobs were filled by overeducated workers, whereas only $34 \%$ according to the modified self-assessment method. ${ }^{5}$ These divergent figures are consistent with those of other studies that measure overeducation on the basis of both job analysis and self-assessment approaches. This may be explained by social desirability bias (Hartog, 2000), resulting in an overestimation of job requirements in the self-assessment approach. However, alternatively, occupational classifications may be relatively inflexible to upgrades in educational requirements. In this latter interpretation the modified self-assessment method discards "apparent" overeducation identified as overeducation by the job analysis method. As already mentioned, since career mobility is less likely for the "apparently overeducated" (Chevalier, 2003), more career mobility may be expected when basing the analysis on the self-assessment method.

\subsection{Descriptive analysis}

Based on the aforementioned information, we determine for each sampled individual the timing at which (s)he entered an adequate job or a job for which (s)he was overeducated since (s)he started searching for a job. 788 young men (55\% of the retained sample) find an adequate job (as measured by job analysis) before the end of the observation period. 546 (38\%) of these men directly entered an adequate job (subsample ' $E$ ', the "control" group), while $242(17 \%)$ were temporarily overeducated before entering the adequate job (subsample 'OE', the "treatment" group). 549 young men (38\%) enter a job for which they are overeducated and do not subsequently transit to an adequate job before they are right censored (subsample 'OC'). 97 (7\%) individuals were right censored before making any transition (subsample ' $C$ ').

The right-censoring for $646(=549+97)$ of the observations occurs for one of the following reasons: (i) end of the observation period and sample attrition (69\% of the 646 right censored observations); (ii)

\footnotetext{
${ }^{4}$ The number of self-assessments is relatively low for some occupations at more detailed levels. Therefore, we base the computation on the most detailed occupational level for which we have at least 20 observations available in our data. For a similar procedure and discussion in the case of realized matches measures, see Verhaest and Omey (2010).

${ }^{5}$ This incidence using the modified self-assessment measure is very similar to the incidence using the standard subjective measure. Further, relying on this alternative procedure, we also investigated the impact of overeducation on earnings and job satisfaction. Also these outcomes were similar to those on the basis of other measures.
} 
transition to a job for which the functional level is not registered (15\%); (iii) return to full time education (7\%); (iv) transition to self-employment (7\%) and (v) transition to disability (2\%).

Figure 1 reports non-parametric Kaplan-Meier estimates of the monthly transition into a first job (irrespectively of whether one is overeducated for it or not) and into a first adequate job (directly or indirectly, after a temporary spell of overeducation). Overeducation is measured according to the job analysis method. The corresponding figure if overeducation is measured by the self-assessment method is reported in Appendix $D$. The median duration until the transition to a first job is 1 month and 29 months until a first transition to an adequate job. This illustrates clearly that most young graduates very rapidly find a job at the start of their career, but also that these graduates are overeducated for most of these jobs, since they enter an adequate job at a much slower rate.

Figure 1: Kaplan-Meier estimates: survival in unemployment until entry in a first job (job analysis method)

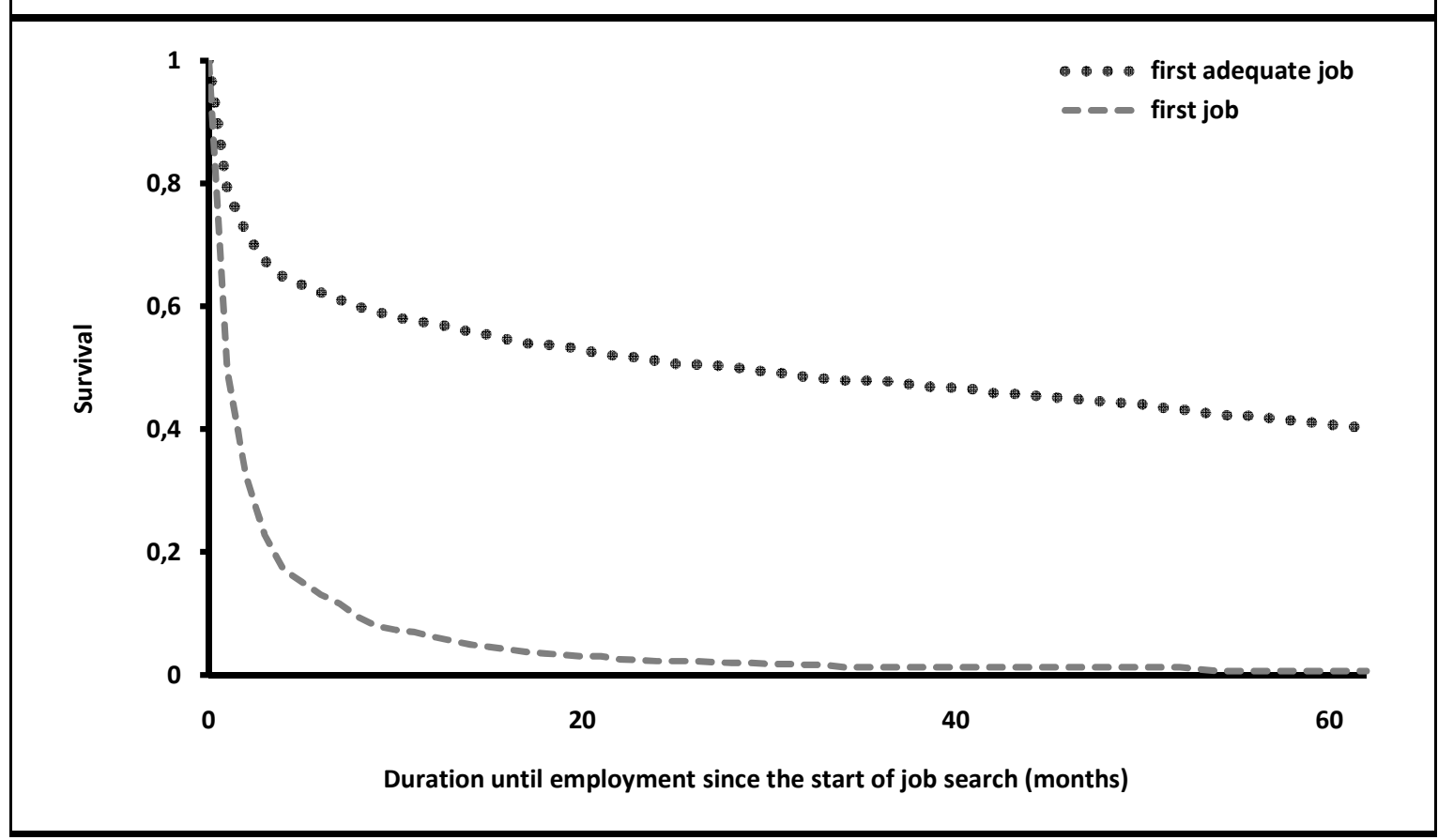

Figure 2 reports the non-parametric Kaplan-Meier estimates of the number of months that elapse after accepting a job for which one is overeducated until entry in an adequate job. The median duration is as high as 110 months. Since the median duration since the start of job search until (direct or indirect) entry into an adequate job is only 29 months, this means that most direct transitions into an adequate job occur much more rapidly than the indirect transitions. However, since this comparison does not take selection on (un)observable characteristics into account, we cannot conclude from this descriptive evidence, that accepting a job for which one is overeducated is a trap 
rather than a stepping stone to an adequate job. Overeducated individuals might have very low chances to enter adequate jobs anyway, so that for these individuals it might have taken even longer before they would have found an adequate job if they would have rejected all jobs for which they were overeducated. The Timing of Events method that we apply in this research takes the selection on (un)observable characteristics into account and leads therefore to a better founded answer to our research question.

Figure 2: Kaplan-Meier estimates: survival until entry in adequate job (job analysis method)

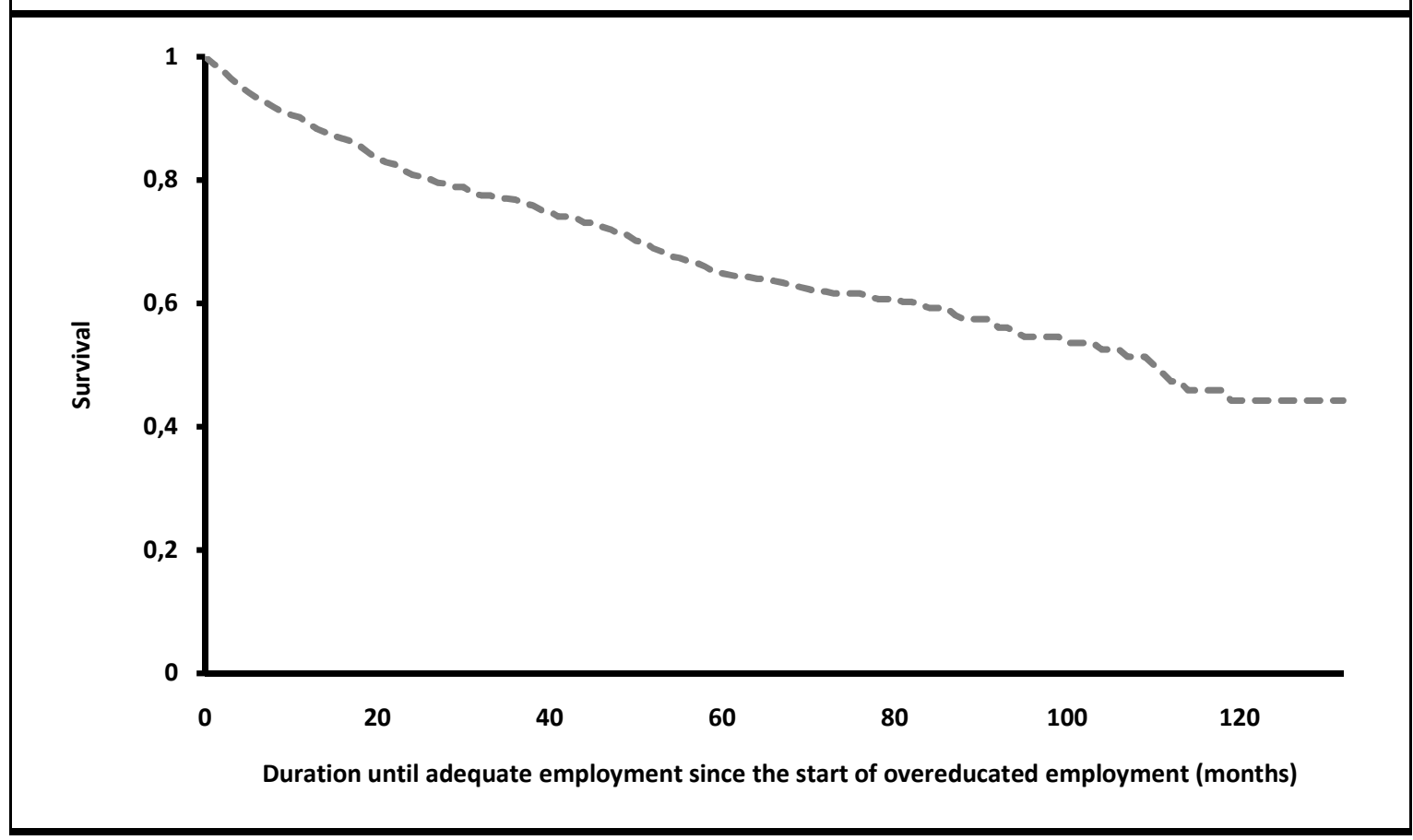

Our analysis controls for a rich set of observed characteristics. A vector of time-constant variables measured before the start of the job search spell captures the respondents' (i) level of educational attainment (highest attained level of education, number of uncertified years of schooling beyond the highest level and an indicator of whether one obtained an additional degree at the same level of education), (ii) school achievement (years of schooling delay at the age of 16 and the grade obtained in tertiary education ${ }^{6}$ ), (iii) school orientation in secondary school (general, technical, vocational or arts), (iv) social background (mother's and father's level of education and migrant status as captured by the nationality of the grandmother at mother's side), (v) birth cohort (1978 or 1980), (vi) work experience during school (internship or student job) and (vii) timing of the start of job search

\footnotetext{
${ }^{6}$ This information is not available at the level of secondary education.
} 
(quarter in the year and number of months since leaving school). In addition, the monthly Belgian youth unemployment rate (ILO definition) is included as a time varying variable as to capture seasonal and business cycle variation. Details concerning some of these variables are outlined in Appendix A.

Table 1: Summary statistics

\begin{tabular}{|c|c|c|c|c|c|}
\hline $\begin{array}{l}\text { Sample: } \\
\text { (Number of individuals): }\end{array}$ & $\begin{array}{l}\text { Total } \\
\text { (1434) }\end{array}$ & $\begin{array}{c}\text { C } \\
(97)\end{array}$ & $\begin{array}{c}\text { E } \\
\text { (controls) } \\
(546)\end{array}$ & $\begin{array}{r}\text { OC } \\
\text { (549) }\end{array}$ & $\begin{array}{c}\text { OE } \\
\text { (treated) } \\
(242)\end{array}$ \\
\hline \multicolumn{6}{|l|}{ Highest level of educational attainment } \\
\hline \multicolumn{6}{|l|}{ Highest attained level of education } \\
\hline Lower secondary education & $0.24(0.43)$ & $0.14(0.35)$ & $0.27(0.44)$ & $0.24(0.43)$ & $0.21(0.41)$ \\
\hline Secondary education & $0.43(0.50)$ & $0.30(0.46)$ & $0.44(0.50)$ & $0.41(0.49)$ & $0.52(0.50)$ \\
\hline Lower tertiary education & $0.17(0.38)$ & $0.22(0.41)$ & $0.19(0.39)$ & $0.14(0.35)$ & $0.17(0.38)$ \\
\hline Higher tertiary education & $0.16(0.37)$ & $0.34(0.48)$ & $0.10(0.31)$ & $0.21(0.41)$ & $0.10(0.30)$ \\
\hline $\begin{array}{l}\text { Additional successful years of education after highest } \\
\text { attained level of education }\end{array}$ & $0.40(0.73)$ & $0.32(0.65)$ & $0.37(0.67)$ & $0.48(0.81)$ & $0.36(0.69)$ \\
\hline Additional degree at highest attained level of education & $0.06(0.23)$ & $0.11(0.32)$ & $0.04(0.19)$ & $0.07(0.25)$ & $0.05(0.23)$ \\
\hline \multicolumn{6}{|l|}{ Schooling achievement } \\
\hline \multicolumn{6}{|l|}{ Tertiary education: grade } \\
\hline No grade & $0.85(0.36)$ & $0.77(0.42)$ & $0.85(0.36)$ & $0.86(0.35)$ & $0.87(0.34)$ \\
\hline With honours (cum laude) & $0.13(0.34)$ & $0.21(0.41)$ & $0.13(0.34)$ & $0.12(0.33)$ & $0.12(0.32)$ \\
\hline With great/highest honours (cum magna/maxima laude) & $0.02(0.14)$ & $0.02(0.14)$ & $0.02(0.14)$ & $0.02(0.14)$ & $0.02(0.14)$ \\
\hline Years of schooling delay (at age of 16) & $0.43(0.60)$ & $0.40(0.64)$ & $0.47(0.65)$ & $0.42(0.57)$ & $0.38(0.54)$ \\
\hline \multicolumn{6}{|l|}{ School orientation at age of 16 in secondary school } \\
\hline General secondary education & $0.35(0.48)$ & $0.57(0.50)$ & $0.33(0.47)$ & $0.35(0.48)$ & $0.30(0.46)$ \\
\hline Technical secondary education & $0.37(0.48)$ & $0.27(0.45)$ & $0.40(0.49)$ & $0.34(0.47)$ & $0.43(0.50)$ \\
\hline Arts secondary education & $0.01(0.11)$ & $0.02(0.14)$ & $0.01(0.10)$ & $0.01(0.10)$ & $0.02(0.13)$ \\
\hline Vocational secondary education & $0.27(0.44)$ & $0.14(0.35)$ & $0.26(0.44)$ & $0.30(0.46)$ & $0.25(0.43)$ \\
\hline \multicolumn{6}{|l|}{ Social background } \\
\hline Mother's educational level & $5.33(3.25)$ & $5.86(3.40)$ & $5.47(3.16)$ & $5.13(3.32)$ & $5.24(3.20)$ \\
\hline Father's educational level & $5.72(3.41)$ & $6.47(3.60)$ & $5.86(3.25)$ & $5.57(3.50)$ & $5.47(3.42)$ \\
\hline Grandmother (mother's side) foreign & $0.06(0.24)$ & $0.13(0.34)$ & $0.07(0.25)$ & $0.04(0.20)$ & $0.06(0.24)$ \\
\hline \multicolumn{6}{|l|}{ Birth cohort (birth year) } \\
\hline 1978 & $0.48(0.50)$ & $0.42(0.50)$ & $0.49(0.50)$ & $0.50(0.50)$ & $0.41(0.49)$ \\
\hline 1980 & $0.52(0.50)$ & $0.58(0.50)$ & $0.51(0.50)$ & $0.50(0.50)$ & $0.59(0.49)$ \\
\hline
\end{tabular}




\begin{tabular}{|c|c|c|c|c|c|}
\hline \multicolumn{6}{|l|}{ Work experience during education } \\
\hline Any internship during education & $0.59(0.49)$ & $0.51(0.50)$ & $0.55(0.50)$ & $0.63(0.48)$ & $0.61(0.49)$ \\
\hline Any student job during education & $0.81(0.40)$ & $0.72(0.45)$ & $0.81(0.39)$ & $0.79(0.41)$ & $0.86(0.34)$ \\
\hline \multicolumn{6}{|l|}{ Timing of the start of job search } \\
\hline \multicolumn{6}{|l|}{ Start of job search: quarter in the year } \\
\hline First quarter & $0.09(0.28)$ & $0.13(0.34)$ & $0.10(0.30)$ & $0.07(0.25)$ & $0.10(0.29)$ \\
\hline Second quarter & $0.17(0.37)$ & $0.10(0.31)$ & $0.18(0.39)$ & $0.16(0.36)$ & $0.17(0.37)$ \\
\hline Third quarter & $0.66(0.47)$ & $0.70(0.46)$ & $0.63(0.48)$ & $0.67(0.47)$ & $0.68(0.47)$ \\
\hline Fourth quarter & $0.09(0.28)$ & $0.06(0.24)$ & $0.09(0.28)$ & $0.10(0.31)$ & $0.06(0.24)$ \\
\hline Months between leaving school and starting job search & $2.04(4.03)$ & $2.61(4.68)$ & $2.12(4.76)$ & $2.03(3.57)$ & $1.67(2.68)$ \\
\hline \multicolumn{6}{|l|}{ Seasonal and business variation } \\
\hline Youth unemployment rate at start date of job search & $18.79(2.69)$ & $19.21(3.12)$ & $18.36(2.75)$ & $19.05(2.54)$ & $18.98(2.59)$ \\
\hline \multicolumn{6}{|c|}{$\begin{array}{l}\text { Reported figures are means and standard deviations in parentheses. Subsample ' } C \text { ' contains men who are right censored before making } \\
\text { any transition during the observation period; subsample ' } E \text { ' contains men who directly transit to an adequate job; subsample 'OC' } \\
\text { contains men who enter a job for which they are overeducated and who are subsequently right censored before making any transition to } \\
\text { an adequate job; subsample 'OE' contains men who are temporarily overeducated before entering an adequate job. Details regarding } \\
\text { some of the explanatory variables are outlined in Appendix } A \text {. }\end{array}$} \\
\hline
\end{tabular}

In Table 1 we report descriptive statistics for these explanatory variables used in the econometric analysis below. We separately report statistics on the four subsamples identified in the beginning of this Subsection: ' $E$ ', 'OE', 'OC' and ' $C$ '. Subsample $C$ is relatively small and contains the most educated graduates, since, as this group studies longer, the observation period is systematically shorter for this group. On the other hand, it comprises more foreign youth, which squares with the well documented negative correlation between foreign ethnicity and labour market success. There are also fewer individuals in this subsample with any internship or student work experience during their educational careers.

There is no clear pattern in the differences observed between the other three subsamples except that in subsample E (the "controls"), which is restricted to youth with a direct transition to adequate employment, the parent's level of education and the number of years of schooling delay at the age of 16 is on average higher, and the youth unemployment rate is lower than in the two other subsamples (OC and $O E$, the "treated"), containing youth who are (first) overeducated. It is a priori unclear in which direction this could have biased the aforementioned descriptive evidence on our research question. 


\section{Econometric model}

\subsection{The selection problem}

We aim at identifying whether an unemployed graduate can accelerate the transition to an adequate job by temporarily accepting a job for which (s)he is overeducated ("the treatment") rather than only accepting adequate jobs, or whether instead (s)he might get trapped in overeducation by following such a strategy. To answer this question, we face a double selection problem. First, young men who are more likely to accept a job for which they are overeducated may have a systematically lower (or higher) likelihood of finding an adequate job than those who are less likely to be overeducated. If we ignore this 'classic selection problem', then a simple comparison of the speed of transition to an adequate job between those who directly enter an adequate and those who do so only after an intermediate period of employment as overeducated worker, will underestimate (overestimate) the treatment effect on this speed. Second, even if there is no systematic relationship between the unobserved determinants of treatment and entry in an adequate job, then we are still confronted with a "dynamic selection problem". Since the treatment does not occur at the start of the unemployment spell, treatment can only occur for youth who did not find an adequate job beforehand. Consequently, the treatment effect is measured for a population that has less chances of finding an adequate job than if it was measured at the start of the unemployment spell. This biases the treatment effect towards zero because the treatment effect is confounded with the unobserved lower chances of finding adequate employment in this population (see e.g. Lancaster, 1990, p. 65). The Timing of Events method proposed by Abbring and van den Berg (2003) takes this double selection problem into account and identifies therefore the true causal impact of a transition to overeducation on the speed of transition to an adequate job. We first write down the econometric model and then discuss why we believe that the main identifying assumptions of the Timing of Events method are satisfied.

\subsection{The econometric model}

In the following, the index $o$ indicates overeducation and the index $e$ refers to adequate employment. The transitions of interest into overeducation and adequate employment are represented by two random latent durations: $T_{o}$ and $T_{e}$, with $t_{o}$ and $t_{e}$ denoting their realizations. We assume that all individual differences in the joint distribution of both durations can be characterized 
by explanatory variables $X$ and $V$. $X$ denotes the observed variables as described in Section 2.3 with realization $x .^{7} V$, on the other hand, is unobservable to the researcher and transition-specific. More concretely, $V$ is a vector $\left(V_{e}, V_{o}\right)$ with realization $\left(V_{e}, V_{o}\right) . X$ and $V$ are assumed to be independently distributed (see Section 3.3 for further discussion).

Abbring and van den Berg (2003) assume that $T_{e}$ and $T_{o}$ are independent conditionally on $X$ and $V$, so that the joint distribution of $\left(T_{o}, T_{e}\right) /(X, V)$ can be written as the product of the distributions of $T_{e} /\left(X, V_{e}\right)$ and $T_{o} /\left(X, V_{o}\right)$ which are in turn completely determined by their hazard rates $\vartheta_{e}\left(t \mid t_{o}, x, V_{e}\right)$ and $\vartheta_{o}\left(t \mid x, v_{o}\right)$, where $t$ is the elapsed job search duration. These hazard rates are then specified according to the following Mixed Proportional Hazard (MPH) form:

$$
\left\{\begin{array}{l}
\ln \vartheta_{o}\left(t \mid x, v_{o}\right)=\ln \lambda_{o}(t)+x^{\prime} b_{o}+v_{o} \\
\ln \vartheta_{e}\left(t \mid t_{o}, x, v_{e}\right)=\ln \lambda_{e}(t)+x^{\prime} b_{e}+\delta\left(t \mid t_{o}, x\right) 1\left(t>t_{o}\right)+v_{e}
\end{array},\right.
$$

where $1($.$) is an indicator function, which is 1$ if the argument is true and 0 otherwise, and $\delta\left(t / t_{0}, x\right)$ is the treatment effect of overeducation on the speed of transition to an adequate job. Observe that it can be any function of $t, t_{0}$ and $x$, but cannot depend on any unobserved factor.

First, in a benchmark specification, we assume that the treatment effect is constant:

\section{Constant treatment effect model}

$$
\delta\left(t \mid t_{o}, x\right)=\delta\left(t \mid t_{o}\right)=\delta_{o}
$$

Clearly, overeducation is a stepping stone (trap) if and only if this constant is significantly positive (negative): the transition to an adequate job increases (decreases) proportionally with this treatment effect.

In the benchmark model we allow for an extension in which the treatment effect depends on both the duration since entry in overeducation $\left(t-t_{0}\right)$ and on the elapsed unemployment duration until entry in overeducated employment $t_{0}$. The first factor $\left(t-t_{0}\right)$ aims at capturing a gradually decreasing locking-in effect and/or steadily growing investment effect. Locking-in may reflect investment in specific human capital (Pissarides, 1994), cognitive decline (Grip et al., 2008), habituation (Verhaest and Omey, 2009) or reduced job-search effort on-the-job. The investment effect reflects the gradually increasing promotion opportunities with work experience, as described in the career mobility theory (Sicherman and Galor, 1990). The dependence on the elapsed unemployment

\footnotetext{
${ }^{7}$ To avoid cumbersome notation, we ignore the presence of the youth unemployment rate as a time-varying covariate.
} 
duration, on the other hand, aims at testing whether long-term unemployed benefit more from a stepping stone effect (if any) than short-term unemployed, since accepting any job might reduce the scarring effects of long-term unemployment. We include quadratic terms to allow for nonlinearity of these effects over time.

\section{Extended model}

$$
\delta\left(t \mid t_{o}\right)=\delta_{0}+\delta_{1} \cdot\left(t-t_{o}\right)+\delta_{2} \cdot\left(t-t_{o}\right)^{2}+\delta_{3} \cdot\left(t_{o}\right)+\delta_{4} \cdot\left(t_{o}\right)^{2}
$$

In Section 4.2, in which we report a number of sensitivity analyses, we discuss some further extensions in which the treatment effect depends on some other explanatory variables.

$\lambda_{o}(t)$ and $\lambda_{e}(t)$ represent the baseline hazard functions for transitions into overeducation and adequate employment. The hazard rate is said to be duration dependent if these functions are timevariant. Positive (negative) duration dependence in the transition into overeducation, respectively adequate employment, means that $\lambda_{o}(t)$, respectively $\lambda_{e}(t)$, are increasing (decreasing) in $t$. We follow the literature by specifying these baseline hazards as piecewise constant:

$$
\left\{\begin{array}{l}
\ln \lambda_{o}(t)=\alpha_{m}^{o} \\
\ln \lambda_{e}(t)=\alpha_{m}^{e}
\end{array} \text { for } t \in\left[t_{m-1}, t_{m}\right),\right.
$$

where $m$ is an indicator of the time interval and where in the application $\mathrm{m} \leq 8$ and $t_{0}=0, t_{1}=1, t_{2}=$ $2, t_{3}=3, t_{4}=4, t_{5}=6, t_{6}=9, t_{7}=18$ and $t_{8}=+\infty$.

We estimate the constant treatment and extended model by Maximum Likelihood. We distinguish between four types of likelihood contributions, conditional on the unobserved heterogeneity distribution, depending on the labour market history of the youth described in Section $2.3 ; I_{c}(V), I_{e}(V)$, $I_{o c}(V)$ and $I_{o e}(V)$. In Appendix $B$ we derive these conditional contributions taking the time-grouped nature of the data into account.

To obtain the unconditional likelihood contributions, we integrate the four conditional contributions over the unobserved heterogeneity distribution. We follow Heckman and Singer (1984) and assume that $\left(v_{e}, v_{o}\right)$ is randomly drawn from a discrete distribution with a finite and a priori unknown number $K$ of points of support. Since we include a constant term in $X, v_{e 1}$ and $v_{o 1}$ are normalized to 0 . The probabilities associated to these points of support are specified as logistic transforms:

$$
p_{k}=\frac{\exp \left(\gamma_{k}\right)}{\sum_{j=1}^{K} \exp \left(\gamma_{j}\right)}, \text { with } k=1,2, \ldots, K \text { and } \gamma_{1}=0
$$


Hence, the likelihood contribution for individual $i$ in subsample $n \in\{c, e, o c, o e\}$ unconditional on unobserved heterogeneity is:

$$
I_{n i}=\sum_{k=1}^{K} p_{k} \cdot I_{n}\left(v_{e k}, v_{o k}\right) \text {, with } n \in\{c, e, o c, o e\}
$$

We can then write the unconditional log-likelihood as the sum of the unconditional individual loglikelihood contributions:

$$
L=\sum_{i=1}^{N}\left[J_{c i} \ln \left(I_{c i}\right)+J_{e i} \ln \left(I_{e i}\right)+J_{o c i} \ln \left(I_{o c i}\right)+J_{o e i} \ln \left(I_{o e i}\right)\right]
$$

where $J_{n i}$ equals 1 if $I_{n i}$ is the contribution of individual $i$ to the likelihood and $J_{n i}$ equals 0 otherwise. We maximize this log-likelihood according to the procedure described in Gaure et al. (2007). In particular, we increase the number of points of support until the likelihood function does not show any improvement and subsequently select the model that minimizes the Akaike Information Criterion (AIC) to reduce the risk of bias induced by an over-parameterized model.

\subsection{Identification}

Unlike some other methods that aim at resolving the selection problem, the Timing of Events method does not require any exclusion restrictions. All observed determinants may affect both the transition to overeducation (the treatment) and the transition to an adequate job (the outcome of interest). However, the method requires another set of identifying assumptions (Abbring and van den Berg, 2003) of which we discuss the credibility now.

1. The method assumes that events do not realize instantaneously, since it exploits the timing of events to identify the true causal effect. In the retained sample individuals gradually enter overeducation or adequate employment over time, so that this first condition is satisfied.

2. Even if the aforementioned events realize gradually over the course of the job search period, the method requires that the timing of these events is known with sufficient precision. The data record transitions with a monthly precision. This time grouping is not problematic to the extent that it is unlikely that two transitions take place within the same month (see Cockx et al., In press, for a discussion). In our data at most one transition can take place within a given month by definition: each month is assigned either to a working or non-working status, depending on the status in which one spends most of the time (see Section 2.1). This does not mean that in reality 
not more than one transition may occur within a month (e.g. short-term employment through temporary work agencies). However, they are regarded unimportant for the job transition process we study.

Even if the time grouping of the data is not problematic, Monte Carlo analysis of Gaure et al. (2007) has shown that that it is important to take, as we do (see Appendix B), this time grouping explicitly into account. However, if one follows this advice the aforementioned Monte Carlo analysis has shown that Abbring and van den Berg (2003)'s method is extremely reliable.

3. The moment at which employment is entered may not be anticipated. Since neither the employer nor the job searcher has in general an interest to postpone hiring once the hiring decision is taken, we believe that the time lag between the moment at which the job was found and the moment at which the job is entered, is relatively short, so that the no-anticipation assumption is approximately satisfied.

4. Observed and unobserved determinants affect the transition rates to overeducation and adequate employment of the untreated individuals proportionally. ${ }^{8}$ This is the so called Mixed Proportional Hazard (MPH) assumption. The aforementioned Monte Carlo analysis of Gaure et al. (2007) has shown that this assumption is crucial, at least if only time constant explanatory variables are available. ${ }^{9}$ We are particularly concerned that the MPH assumption is not satisfied across levels of educational attainment and that this therefore may be a source of bias. The reason for this concern is that the highest educated individuals have more opportunities to be overeducated, simply because accepting any job with requirements below the highest level of educational attainment leads to overeducation. By contrast, individuals with a lower secondary degree are only overeducated if they accept a job that does not require any educational attainment. We therefore perform a sensitivity analysis in which we estimate the treatment effects separately for each level of educational attainment, relaxing thereby the proportionality assumption in this dimension.

5. There should be at least two continuous explanatory variables that are not linearly dependent. This condition is not strictly satisfied, since variables such as parent's education, number of years of schooling delay, additional years of education beyond the highest degree, the elapsed number of months between school-leaving and the start of job search are multivalued, but not

\footnotetext{
${ }^{8}$ Observable factors may affect the treatment effect non-proportionally. The treatment effect may, however, not depend on unobservables unless additional assumptions are imposed (see, e.g., Richardson and van den Berg, 2008).

${ }^{9}$ Note that despite the youth unemployment rate is a time-varying explanatory variable, it is of no use for identification, since its variation is the same across all observations in the sample.
} 
continuous. By contrast, the (time-varying) youth unemployment rate can be regarded as a continuous covariate. Moreover, Gaure et al. (2007, p. 1186) conclude on the basis of their extensive Monte Carlo analysis that, with "some exogenous variation in hazard rates over calendar time, no subject-specific covariates are required in order to identify treatment and spell-duration effects".

6. $\quad X$ and $V$ should be independently distributed. This is a strong assumption, but it can be relaxed if one is willing to assume that the unobserved heterogeneity conditional on $x$ can be written as $v_{k} \exp \left(x \mu_{k}\right)$ (for $\left.k=e, o\right)$, where $V_{k}$ is then independently distributed from $X$ and where $\mu_{k}$ is some unknown parameter vector. In this case it is not difficult to see that the treatment effect below is still consistently estimated, but that the parameters associated to the covariates of $x$ can no longer be given a structural interpretation. This is very similar to Chamberlain's (1980) widely used extension of the random effect probit model (see Cockx et al., In press, for further discussion).

7. Finally, $T_{e}$ and $T_{o}$ are independent conditionally on $X$ and $V$. This means that the hazard rates to adequate employment and overeducation may not depend on unobserved time-varying shocks. Even if we cannot exclude bias induced by such shocks at the individual level, the inclusion of the time-varying youth unemployment rate aims at capturing seasonal and business cycle shocks at the aggregate level.

\section{Results}

\subsection{Main results}

In this subsection we first discuss the main results. In a subsequent subsection we report a number of sensitivity analyses. In the main text we focus on the treatment effects. The complete estimation results can be found in Appendix $C$.

On the basis of the AIC we retain for both outlined specifications of the treatment effect (constant and extended) the model with three heterogeneity types. However, the probability assigned to one of the points of support is small (4\%), so that the estimates are not very different from a model with two points of support. This may also explain why the correlation between $V_{e}$ and $V_{o}$ is so close to 1 
(cf. Appendix C): the model with two points of support is equivalent to a model with a one-factor specification for which the correlation can only be 0,1 or -1 . A positive correlation means that the model identifies a positive selection on unobservables. Hence, the model that does not correct for unobserved heterogeneity overestimates the treatment effect. This can be verified by comparing the treatment effects of the benchmark models that ignore unobserved heterogeneity as reported in Table C-2 (Appendix $C$ ) to the treatment effects reported in Table 2 below.

The main estimation results of the benchmark model are summarized in Table 2. A more comprehensive presentation is reported in Table C-1. As shown by panel A, the point estimate of the treatment effect in our benchmark model is very negative and highly significant. In the full sample the monthly transition rate into adequate employment drops by about $96 \%{ }^{10}$ in the subsequent months after entering overeducated employment. This supports the hypothesis of the descriptive analysis in Section 2.3 that overeducation is a trap and not a stepping stone to adequate employment.

\begin{tabular}{|c|c|c|}
\hline & $\begin{array}{c}\text { A. Constant treatment } \\
\text { effect model }\end{array}$ & B. Extended model \\
\hline \multicolumn{3}{|l|}{ Treatment effect } \\
\hline Constant: $\delta_{0}$ & $\begin{array}{c}-3.171^{* * *} \\
(0.287)\end{array}$ & $\begin{array}{c}-4.080^{* * *} \\
(0.354)\end{array}$ \\
\hline Interaction with $\left(\mathrm{t}-\mathrm{t}_{0}\right): \delta_{1}$ & & $\begin{array}{l}-0.014 \\
(0.012)\end{array}$ \\
\hline Interaction with $\left(t-t_{0}\right)^{2}: \delta_{2} * 100$ & & $\begin{array}{c}0.011 \\
(0.011)\end{array}$ \\
\hline Interaction with $\mathrm{t}_{0}: \delta_{3}$ & & $\begin{array}{c}0.232^{* * *} \\
(0.088)\end{array}$ \\
\hline Interaction with $\left(\mathrm{t}_{0}\right)^{2}: \delta_{4}$ & & $\begin{array}{l}-0.004 \\
(0.004)\end{array}$ \\
\hline Log-likelihood & -4606.553 & -4594.661 \\
\hline AIC & 9347.107 & 9331.321 \\
\hline Parameters & 67 & 71 \\
\hline Observations & 1434 & 1434 \\
\hline
\end{tabular}

${ }^{10} 0.96=1-\exp (-3.171)$ 
Panel B summarizes the estimation results for the extended model. First, the point estimates for $\delta_{1}$ and $\delta_{2}$, capturing the effect heterogeneity in the elapsed duration since inflow into a job for which one is overeducated, are not statistically significant. Neither the locking-in nor the investment effects seem to matter much therefore, or both effects might counteract. Second, by contrast, $\delta_{3}$ is highly significant. This means that young men delay the transition to an adequate job by accepting jobs for which they are overeducated more at the start of the unemployment spell rather than later on. The magnitude of this adverse effect declines with unemployment duration and, if we ignore the insignificant second order term $\left(\delta_{4}\right)$, it becomes even positive beyond an unemployment duration of 17.6 months. ${ }^{11}$ This would be an important finding, since it would mean that only short-term unemployed graduates get trapped in overeducation. Long-term unemployed would accelerate the transition to an adequate job by temporarily accepting a job for which they are overeducated. However, this conclusion crucially hinges on ignoring the insignificant second order term $\delta_{4}$. If we take it into account, the treatment effect attains a maximum at 29 months ${ }^{12}$ and decreases again thereafter. At this maximum the transition rate to an adequate job after entry in overeducated overeducated is still $51 \%{ }^{13}$ below what it would have been if one would have only accepted adequate jobs. In the sensitivity analysis below, we will argue that this is the correct interpretation of our findings. The transition to overeducation is thus never a stepping stone, but always a trap, even if the findings are consistent with the hypothesis that one can reduce the negative scarring effect of unemployment duration by accepting a job for which one is overeducated. Note that the transition rate to adequate jobs exhibits clear negative duration dependence while that to jobs for which one is overeducated increases with unemployment duration (cf. Table C-1 in Appendix C).

We briefly discuss some secondary results reported for the extended model. Note that a structural interpretation of the coefficients for the observed covariates is hazardous given the potential dependence between $X$ and $V .{ }^{14}$ We find that the employment gap between foreign and native youth is significantly larger for the transition into jobs for which one is overeducated than for the transition into adequate jobs. In addition we get a stable positive effect of an honours degree in tertiary education on the transition to adequate employment. Conducting any student work during education affects the transition to overeducated and adequate employment with a similar magnitude.

\footnotetext{
${ }^{11} 17.6=4.08 / 0.232$.

${ }^{12} 29=0.232 /(2 * 0.004)$.

${ }^{13}-4.08+0.232 * 29-0.004 * 29^{2}=-0.716$ and $1-\exp (-0.716)=0.51$.

${ }^{14}$ See the discussion of the identifying assumption 6 in Section 3.3 .
} 
The fact that the higher educated are ceteris paribus less likely to leave unemployment is most probably a consequence of only retaining young men in the sample who started job search after leaving school: this group is a negatively selected subsample of the higher educated. One might argue that this might cause non-proportionality of the unobserved determinants of the transitions from unemployment, since for lower levels of education this negative selection is less an issue because they are less likely to find a job immediately after leaving school. Conditional on the level of educational attainment, one might therefore expect higher $V$ 's for the lower educated than for the higher educated. We will try to address this issue in the first part of the sensitivity analysis reported in the next subsection.

\subsection{Sensitivity analysis}

In Table 3 we report some robustness checks of our main result that young men get trapped in jobs for which they are overeducated. First, we re-estimate our model separately on the four subsamples defined according to their highest attained level of education. ${ }^{15}$ We do so because we are particularly concerned with the failure of the MPH assumption across levels of educational attainment (see our discussion of identifying assumption 4 in Section 3.3 as well as our discussion at the end of the previous subsection). However, panels A1 until A4 indicate that the estimates of the treatment effects are not different across these subgroups. For all educational levels, accepting a job for which one is overeducated prolongs the transition to an adequate job. Moreover, $\delta_{1}$ and $\delta_{2}$ are insignificant for all subsamples. As in the pooled analysis, $\delta_{3}$ is large and positive, but only significantly so for the two lowest levels of education. Finally, $\delta_{4}$ is systematically negative and even significantly so (at the $10 \%$ level) for graduates with a secondary education. Moreover, if this quadratic term is taken into account, the treatment effect remains negative for all possible unemployment durations. These findings are therefore reassuring and consistent with the main findings reported in Section 4.1.

In a second sensitivity test we introduce more heterogeneity in the treatment effect. On the one hand it could be argued that in a booming economy it would be easier to promote from overeducation to an adequate job. On the other hand we want to capture the difference in treatment effects according to differences in skills, since one may argue that, within each educational

\footnotetext{
${ }^{15}$ For the models reported in panels $A$ and $C$ the lowest AIC was obtained with two points of support, while for the model reported in panel B 3 points of support were required. For the model reported in panel D one point of support was optimal. This is probably due to the relatively small number of observations in this sample. Since the findings of this model are quite different from the models accounting for heterogeneity and since among the models that account for heterogeneity the one with 3 points of support yields the lowest AIC, we choose to report the parameter estimates of the latter model rather than those of the model that disregards unobserved heterogeneity.
} 
level, the higher skilled transit faster to an adequate job. This would be evidence of promotion induced by genuine overeducation, since the more skilled are more likely to be genuinely overeducated and the latter are more likely to promote (cf. the discussion in Section 1). To this end, we further include interactions with the unemployment rate and the years of schooling delay at the age of 16. Panel B indicates that neither of the two additional interaction effects are significant.

\section{Extended model (sensitivity analysis 2)}

$$
\delta\left(t \mid t_{o}\right)=\delta_{0}+\delta_{1} \cdot\left(t-t_{o}\right)+\delta_{2} \cdot\left(t-t_{o}\right)^{2}+\delta_{3} \cdot\left(t_{o}\right)+\delta_{4} \cdot\left(t_{o}\right)^{2}+\delta_{5} \cdot u r_{t}+\delta_{6} \cdot \text { delay16 }
$$

Thirdly, we test the robustness of our results to the alternative measure of overeducation as defined in Section 2.2. This alternative measure results in a rearrangement of the sample of graduates over the four subsamples: subsamples ' $C$ ', ' $E$ ', 'OC' and 'OE' comprise 97, 886, 267 and 184 individuals respectively. As explained in Section 2.2, according to this alternative measure the degree of overeducation is much lower and therefore it is more likely that genuine overeducation is captured. If so, the likelihood of promotion should increase. However, the estimated treatment effects are very comparable to those of the benchmark model. A first main difference is that the quadratic interaction term with unemployment duration $\left(\delta_{4}\right)$ is now very significantly different from zero. This provides further confirmation that we should take this interaction term into account when interpreting the results. A second main difference is the significance of $\delta_{1}$ and $\delta_{2}$, the interactions with the time since entry in a job for which one is overeducated $\left(t-t_{0}\right)$ : the entrapment effect is (slightly) more pronounced during the first 70 months.

\begin{tabular}{|c|c|c|c|c|c|c|}
\hline \multicolumn{7}{|c|}{ Table 3: Sensitivity analysis - estimates for the selected models } \\
\hline & $\begin{array}{c}\text { A1. } \\
\text { Sensitivity } \\
\text { analysis } 1 \\
\text { Subpopulation } \\
\text { "Lower } \\
\text { secondary } \\
\text { education" }\end{array}$ & $\begin{array}{c}\text { A2. } \\
\text { Sensitivity } \\
\text { analysis } 1 \\
\text { Subpopulation } \\
\text { "Higher } \\
\text { secondary } \\
\text { education" }\end{array}$ & $\begin{array}{c}\text { A3. } \\
\text { Sensitivity } \\
\text { analysis } 1 \\
\text { Subpopulation } \\
\text { "Lower } \\
\text { tertiary } \\
\text { education" }\end{array}$ & $\begin{array}{c}\text { A4. } \\
\text { Sensitivity } \\
\text { analysis } 1 \\
\text { Subpopulation } \\
\text { "Higher } \\
\text { tertiary } \\
\text { education" }\end{array}$ & $\begin{array}{c}\text { B. } \\
\text { Sensitivity } \\
\text { analysis } 2 \\
\text { Additional } \\
\text { treatment } \\
\text { interactions }\end{array}$ & $\begin{array}{c}\text { C. } \\
\text { Sensitivity } \\
\text { analysis } 3 \\
\text { Modified } \\
\text { subjective } \\
\text { overeducation } \\
\text { Measure }\end{array}$ \\
\hline \multicolumn{7}{|l|}{ Treatment effect } \\
\hline Constant: $\delta_{0}$ & $\begin{array}{c}-4.322^{* * *} \\
(0.618)\end{array}$ & $\begin{array}{c}-4.893^{* * *} \\
(0.689)\end{array}$ & $\begin{array}{c}-4.149^{* * *} \\
(0.606)\end{array}$ & $\begin{array}{l}-4.044 \\
(2.906)\end{array}$ & $\begin{array}{c}-4.216^{* * *} \\
(0.605)\end{array}$ & $\begin{array}{c}-4.103^{* * *} \\
(0.267)\end{array}$ \\
\hline Interaction with $\left(\mathrm{t}-\mathrm{t}_{0}\right): \delta_{1}$ & $\begin{array}{l}-0.006 \\
(0.022)\end{array}$ & $\begin{array}{l}-0.006 \\
(0.017)\end{array}$ & $\begin{array}{c}0.015 \\
(0.042)\end{array}$ & $\begin{array}{c}0.081 \\
(0.088)\end{array}$ & $\begin{array}{l}-0.015 \\
(0.012)\end{array}$ & $\begin{array}{c}-0.045^{* * *} \\
(0.016)\end{array}$ \\
\hline
\end{tabular}




\begin{tabular}{|c|c|c|c|c|c|c|}
\hline $\begin{array}{l}\text { Interaction with }\left(t-t_{0}\right)^{2}: \\
\delta_{2} * 100\end{array}$ & $\begin{array}{c}0.005 \\
(0.018)\end{array}$ & $\begin{array}{c}0.011 \\
(0.015)\end{array}$ & $\begin{array}{l}-0.020 \\
(0.053)\end{array}$ & $\begin{array}{l}-0.143 \\
(0.125)\end{array}$ & $\begin{array}{c}0.012 \\
(0.010)\end{array}$ & $\begin{array}{l}0.032^{* *} \\
(0.015)\end{array}$ \\
\hline Interaction with $\mathrm{t}_{0}: \delta_{3}$ & $\begin{array}{c}0.357^{* * *} \\
(0.121)\end{array}$ & $\begin{array}{l}0.421^{* * *} \\
(0.152)\end{array}$ & $\begin{array}{c}0.219 \\
(0.214)\end{array}$ & $\begin{array}{c}0.200 \\
(0.350)\end{array}$ & $\begin{array}{l}0.229 * * \\
(0.090)\end{array}$ & $\begin{array}{c}0.320^{* * *} \\
(0.072)\end{array}$ \\
\hline Interaction with $\left(\mathrm{t}_{0}\right)^{2}: \delta_{4}$ & $\begin{array}{l}-0.008 \\
(0.005)\end{array}$ & $\begin{array}{l}-0.011^{*} \\
(0.006)\end{array}$ & $\begin{array}{l}-0.009 \\
(0.013)\end{array}$ & $\begin{array}{l}-0.003 \\
(0.012)\end{array}$ & $\begin{array}{l}-0.004 \\
(0.004)\end{array}$ & $\begin{array}{c}-0.009 * * \\
(0.003)\end{array}$ \\
\hline $\begin{array}{l}\text { Interaction with } \\
\text { unemployment rate: } \delta_{5}\end{array}$ & & & & & $\begin{array}{c}0.012 \\
(0.028)\end{array}$ & \\
\hline $\begin{array}{l}\text { Interaction with years of } \\
\text { schooling delay (age of } 16 \text { ): } \delta_{6}\end{array}$ & & & & & $\begin{array}{l}-0.222 \\
(0.153)\end{array}$ & \\
\hline Log-likelihood & -1024.419 & -1978.052 & -765.183 & -670.047 & -4593.340 & -4058.329 \\
\hline$\overline{A I C}$ & 2156.839 & 4078.103 & 1648.365 & 1466.093 & 9332.680 & 8258.657 \\
\hline Parameters & 54 & 61 & 59 & 63 & 73 & 71 \\
\hline Observations & $338^{16}$ & 620 & $244^{17}$ & 230 & 1434 & 1434 \\
\hline $\begin{array}{l}\text { Standard errors in parentheses } \\
\text { level. }\end{array}$ & & & & & & 10 \\
\hline
\end{tabular}

In a final sensitivity analysis we also included the field of tertiary education as main explanatory variables. However, these variables were hardly significant in neither of the hazard rates and influenced the findings only negligibly. ${ }^{18}$

\section{Discussion}

The finding that overeducation strongly retards the transition to adequate employment clearly challenges Sicherman and Galors' (1990) career mobility thesis. This adds to the more indirect evidence provided by other researchers who studied upward mobility of overeducated individuals, and who concluded that many individuals remain overeducated for very long periods (cf. Section 1). It also confirms the conclusions of studies that test this theory in an indirect way by investigating the relationship between overeducation and training participation or skill acquisition. These studies in general find that overeducated workers participate less often in training and acquire less additional

\footnotetext{
${ }^{16} 1$ individual is dropped since (s)he was the only one with arts secondary education at the age of 16 causing optimization problems.

${ }^{17} 1$ individual is dropped since (s)he was the only one with vocational secondary education at the age of 16 causing optimization problems.

${ }^{18}$ These results are not reported, but are available upon request.
} 
skills than adequately educated workers with a similar educational background (Robst, 1995; van Smoorenburg and van der Velden, 2000; Büchel and Mertens, 2004; Verhaest and Omey, In press).

An often-formulated criticism on the literature of overeducation is that many workers are only "apparently overeducated" (Chevalier, 2003; Green and McIntosh, 2007), i.e. because of occupational upgrading and/or lower quality of human capital, they are formally overeducated but not overskilled. Hence, for these individuals, making a transition to a job for which they are formally adequately educated may simply be not an option. While this might be true for some of the individuals, we have no indications that this is the main driver of our results. First, by focusing our analysis on graduates we do not face the problem that work experience confounds the measure of overeducation. This reduces the likelihood of mismeasuring overeducation. Second, we accounted for selection on unobservables, implying that our basic estimates are likely reflecting the true causal effect of overeducation and not just unobserved ability (Leuven and Oosterbeek, 2011). Thirdly, additional estimates did not deliver indications of heterogeneous effects depending on skill level as measured by the years of schooling delay. Finally, our results were largely similar if based on an adapted subjective overeducation measure which is arguably a better measure of genuine overeducation.

If overeducation is not a stepping stone to an adequate job, one may wonder why? What explains the strong entrapment effect immediately after entrance into overeducation? And why does this entrapment effect not decrease later on? An explanation for the strong initial entrapment effect may be that, by accepting a position that does not match with one's level of educational attainment, the worker may transmit a negative signal to prospective employers (McCormick, 1990). Furthermore, it may be difficult to maintain the same job search intensity on-the-job than when one is unemployed. If so, this may also reduce the incentive for employers to create vacancies for adequately matched jobs and thereby reinforce the low transition rate to an adequate job (see Dolado et al., 2009). ${ }^{19}$ The entrapment effect might not decrease over time as a consequence of investments in specific human capital (Pissarides, 1994), cognitive decline (de Grip et al., 2008), or habituation (Verhaest and Omey, 2009).

Given the strong entrapment effect of overeducation, we need to understand why individuals are prepared to accept such jobs. One explanation is that individuals are credit constrained. Since schoolleavers are only entitled to unemployment benefits after nine months of registered unemployment, this is a natural explanation, especially so if they are no longer financially dependent on their parents income. $15 \%$ of the individuals in the sample retained for the analysis left the parental home at the

\footnotetext{
${ }^{19}$ The low likelihood of finding an adequate position may also be explained by an efficiency wage type of argument (Skott, 2006).
} 
moment at which they started job search. Furthermore, after expiration of this waiting period, the benefit level is low. For singles and cohabiting individuals it is not very different from the meanstested social assistance benefit level. ${ }^{20}$

But even without credit constraints, it may be optimal to accept such jobs. First, the financial and psychological costs of overeducation are, although significant, still relatively modest in comparison to those of being unemployed (Verhaest and Omey, 2009). Albrecht and Vroman (2002) developed a matching model in which they show that it may be optimal for skilled workers to accept unskilled jobs as long as the productivity differences between skilled and unskilled jobs are not too large. In that case, the expected surplus of earnings resulting from future adequate employment no longer outweighs the income loss resulting from unemployment. Note that the argument applies even if the model did not allow the high skilled workers to continue search on the job for which they are overeducated. This feature is consistent with strong entrapment. Second, the likelihood of finding an adequate job may be rather low anyway due to scarring effects of unemployment duration. By accepting a job for which one is overeducated, these scarring effects may be reduced. This is consistent with our findings that the transition rate to adequate jobs exhibits negative duration dependence ${ }^{21}$ and that entrapment in overeducation decreases with unemployment duration.

\section{Conclusion}

In this research project we investigated whether overeducation at the start of the career speeds up the transition to adequate employment. Contrary to many other contributions in this research area, we handled selection on both observables and unobservables. For this, we applied the Timing of Events approach. Our findings indicate that, even for long-term unemployed young people, accepting a job for which one is overeducated strongly retards the transition to an adequate job. This result

\footnotetext{
${ }^{20}$ Depending on factors such as cohabitation status and number of children, the unemployment benefit is only 4 - $24 \%$ higher than the social assistance benefit level (source: National Employment Office (NEO) and Federal Public Service for Social Integration (FPS SI) of the Belgian government). In addition, in contrast to beneficiaries of social assistance, the unemployed are usually not entitled to reduced rates of telecommunication, electricity, heating and public transport.

${ }^{21}$ Note that this is only the case if we measure overeducation according to the job analysis method. If we measure it by the modified subjective method, the duration dependence of the transition rate to both adequate jobs and jobs for which one is overeducated is positive (cf. Table C-3, panel C in Appendix C). We have no clear explanation for this finding.
} 
was found to be robust against various sensitivity checks. We advanced some explanations of why unemployed graduates may nevertheless choose for such jobs and why they do not quickly transit to a job that matches with their level of educational attainment.

From a policy point of view, it is important to stress that one cannot conclude from this study that a worker should rather continue searching for an adequate job than accepting a job for which one is overeducated. Individuals who choose for this strategy will definitely remain longer unemployed, which can be socially less desirable than being employed in a job that does not match the acquired educational attainment. However, if a policy maker aims at matching unemployed graduates to an adequate job as soon as possible, (s)he better does not force them to accept jobs for which they are overeducated, since these jobs certainly do not act as a stepping stones.

\section{Appendix A: Additional information about some explanatory variables}

Table A-1: Additional information about some explanatory variables

\begin{tabular}{|c|c|}
\hline Variable name & Variable details \\
\hline $\begin{array}{l}\text { Grandmother } \\
\text { (mother's side) foreign }\end{array}$ & $\begin{array}{l}\text { Dummy = } 1 \text { if the respondent's grandmother on mother's side has not the Belgian nor a North American, } \\
\text { British, Scandinavian, Western European or Australian nationality. }\end{array}$ \\
\hline $\begin{array}{l}\text { Highest attained level } \\
\text { of education }\end{array}$ & $\begin{array}{l}\text { Unless otherwise stated, variables reflecting the educational career of the respondent are measured at the } \\
\text { moment the youngster stops schooling (for the first time). }\end{array}$ \\
\hline $\begin{array}{l}\text { Father's (mother's) } \\
\text { educational level }\end{array}$ & $\begin{array}{l}\text { This variable measures for the parent the number of successful schooling years beyond primary school. E.g. it } \\
\text { is equal to } 6 \text { if the parent has successfully completed general or technical secondary education, but did not } \\
\text { successfully complete any year of higher education. }\end{array}$ \\
\hline $\begin{array}{l}\text { Youth unemployment } \\
\text { rate }\end{array}$ & $\begin{array}{l}\text { This is the seasonally unadjusted monthly Belgian unemployment rate for males aged less than } 25 \text { years } \\
\text { following the ILO definition (source: Eurostat). }\end{array}$ \\
\hline
\end{tabular}




\section{Appendix B: The likelihood contributions ${ }^{22}$}

The first conditional contribution concerns individuals without any transition into (overeducated or adequate) employment before the end of month $m_{c}$ after which they are right censored due to one of the reasons described in Section 2.1.

$$
I_{c}(v)=\exp \left[-\sum_{i=1}^{m_{c}} \vartheta_{e}^{A}\left(t_{i} \mid t_{o}, x, v_{e}\right)+\vartheta_{o}\left(t_{i} \mid x, v_{o}\right)\right]
$$

In the above expression subscript $A$ ("ante") refers to no prior experience in overeducated employment (subscript $P$ ("post") in other expressions will label hazard rates into adequate employment after some prior experience in overeducation).

The second contribution pertains to individuals who find an adequate job in month $m_{e}$ without any prior experience in overeducation.

$$
\begin{gathered}
l_{e}(v)=\frac{\vartheta_{e}^{A}\left(t_{m_{e}} \mid t_{o}, x, v_{e}\right)}{\vartheta_{e}^{A}\left(t_{m_{e}} \mid t_{o}, x, V_{e}\right)+\vartheta_{o}\left(t_{m_{e}} \mid x, v_{o}\right)} \times \\
\exp \left[-\sum_{i=1}^{m_{e}-1} \vartheta_{e}^{A}\left(t_{i} \mid t_{o}, x, v_{e}\right)+\vartheta_{o}\left(t_{i} \mid x, v_{o}\right)\right] \times\left[1-\exp \left[-\vartheta_{e}^{A}\left(t_{m_{e}} \mid t_{o}, x, v_{e}\right)-\vartheta_{o}\left(t_{m_{e}} \mid x, v_{o}\right)\right]\right.
\end{gathered}
$$

Expression ( $B-2)$ can be interpreted as a competing risk model in which the first factor is the probability of leaving unemployment for adequate employment given that one leaves unemployment in month $m_{e}$ and in which the subsequent factors express the chance on leaving unemployment in month $m_{e}$ (third factor) after staying unemployed until month $m_{e}-1$ (second factor).

The third contribution concerns individuals who find a job for which one is overeducated in month $m_{o}$ without any subsequent transition into adequate employment before the end of month $m_{c}$ after which they are right censored.

\footnotetext{
${ }^{22}$ See Cockx et al. (2010) for a detailed derivation.
} 


$$
\begin{gathered}
I_{o c}(v)=\frac{\vartheta_{o}\left(t_{m_{o}} \mid x, v_{o}\right)}{\vartheta_{e}^{A}\left(t_{m_{o}} \mid t_{o}, x, v_{e}\right)+\vartheta_{o}\left(t_{m_{o}} \mid x, v_{o}\right)-\vartheta_{e}^{P}\left(t_{m_{o}} \mid t_{o}, x, v_{e}\right)} \\
\times \exp \left[-\sum_{i=1}^{m_{o}-1} \vartheta_{e}^{A}\left(t_{i} \mid t_{o}, x, v_{e}\right)+\vartheta_{o}\left(t_{i} \mid x, v_{o}\right)\right] \\
\times\left[\exp \left[-\vartheta_{e}^{P}\left(t_{m_{o}} \mid t_{o}, x, v_{e}\right)\right]-\exp \left[-\vartheta_{e}^{A}\left(t_{m_{o}} \mid t_{o}, x, v_{e}\right)-\vartheta_{o}\left(t_{m_{o}} \mid x, v_{o}\right)\right]\right. \\
\times \exp \left[-\sum_{j=m_{o}+1}^{m_{c}} \vartheta_{e}^{P}\left(t_{j} \mid t_{o}, x, v_{e}\right)\right]
\end{gathered}
$$

The first factor of this expression represents the probability of leaving unemployment for overeducated employment given that one leaves unemployment in month $m_{O}$ and does not immediately transit to adequate employment. Next, the subsequent two factors express the probability of leaving unemployment in month $m_{O}$ without transiting immediately to adequate employment conditional on remaining unemployed until month $m_{0}-1$. The last factor equals the survival probability in overeducated unemployment until the month $m_{c}$ at which one is censored.

The last contribution relates to individuals who first transit to a job for which they are overeducated in month $m_{o}$ and subsequently to an adequate job in month $m_{e}$. Expression (B-4) corresponds to (B-3) except that it is multiplied by (i) the probability of leaving overeducated employment in month $m_{e}$ for adequate employment (the last factor) and (ii) the survival probability in overeducated unemployment until month $m_{e}-1$ (the before last factor).

$$
\begin{gathered}
I_{o e}(v)=\frac{\vartheta_{o}\left(t_{m_{o}} \mid x, v_{o}\right)}{\vartheta_{e}^{A}\left(t_{m_{o}} \mid t_{o}, x, v_{e}\right)+\vartheta_{o}\left(t_{m_{o}} \mid x, v_{o}\right)-\vartheta_{e}^{P}\left(t_{m_{o}} \mid t_{o}, x, v_{e}\right)} \\
\times \exp \left[-\sum_{i=1}^{m_{o}-1} \vartheta_{e}^{A}\left(t_{i} \mid t_{o}, x, v_{e}\right)+\vartheta_{o}\left(t_{i} \mid x, v_{o}\right)\right] \\
\times\left[\exp \left[-\vartheta_{e}^{P}\left(t_{m_{o}} \mid t_{o}, x, v_{e}\right)\right]-\exp \left[-\vartheta_{e}^{A}\left(t_{m_{o}} \mid t_{o}, x, v_{e}\right)-\vartheta_{o}\left(t_{m_{o}} \mid x, v_{o}\right)\right]\right. \\
\times \exp \left[-\sum_{j=m_{o}+1}^{m_{e}-1} \vartheta_{e}^{P}\left(t_{j} \mid t_{o}, x, v_{e}\right)\right] \times\left[1-\exp \left[-\vartheta_{e}^{P}\left(t_{m_{e}} \mid t_{o}, x, v_{e}\right)\right]\right.
\end{gathered}
$$




\section{Appendix C: Complete estimation results}

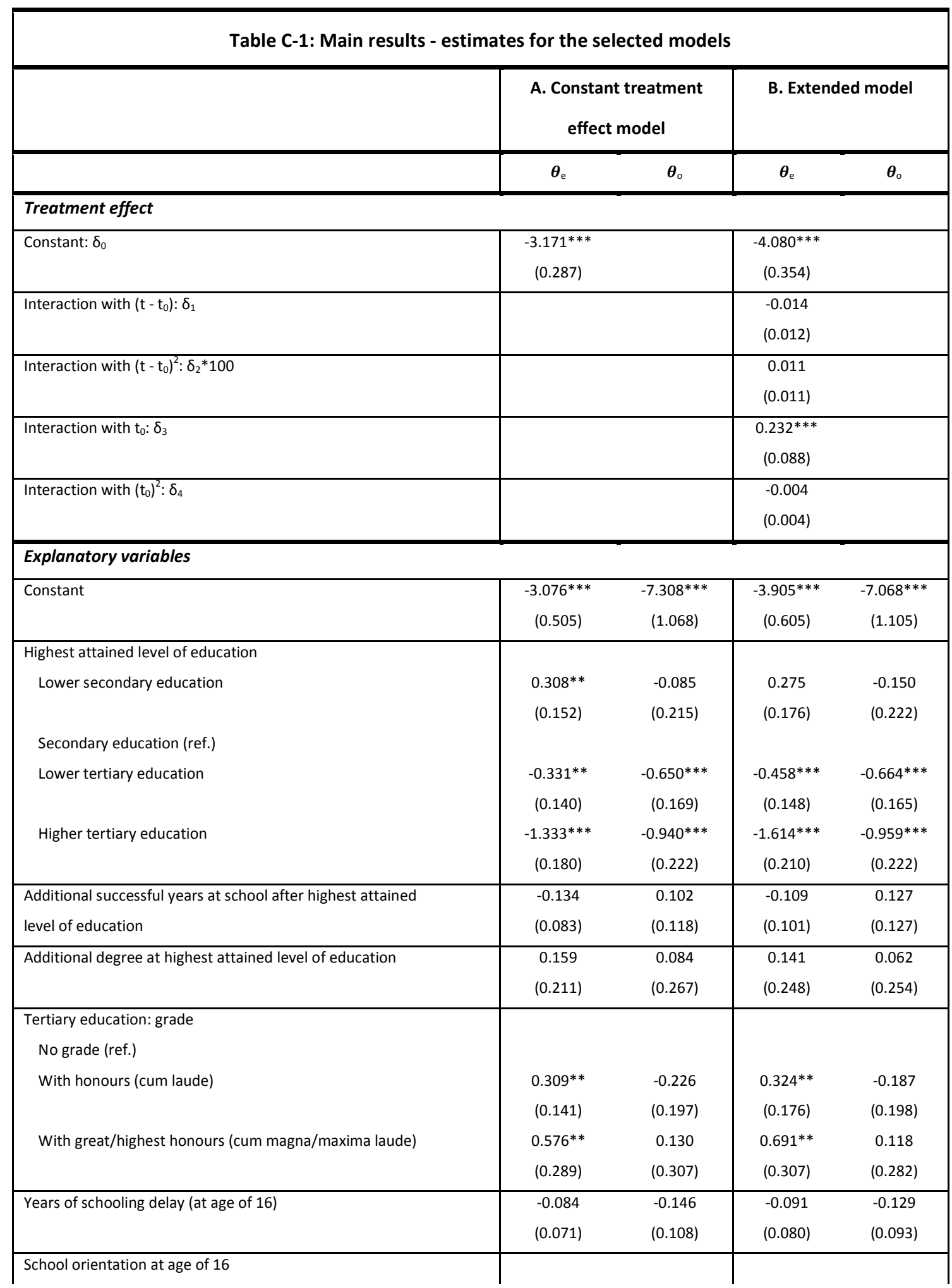




\begin{tabular}{|c|c|c|c|c|}
\hline General secondary education & $\begin{array}{c}-0.197 * \\
(0.105)\end{array}$ & $\begin{array}{l}-0.226 \\
(0.156)\end{array}$ & $\begin{array}{l}-0.211^{*} \\
(0.121)\end{array}$ & $\begin{array}{l}-0.223 \\
(0.140)\end{array}$ \\
\hline \multicolumn{5}{|l|}{ Technical secondary education (ref.) } \\
\hline \multirow[t]{2}{*}{ Arts secondary education } & 0.037 & 0.636 & 0.002 & 0.525 \\
\hline & (0.396) & $(0.520)$ & $(0.402)$ & $(0.456)$ \\
\hline \multirow[t]{2}{*}{ Vocational secondary education } & $-0.280 * *$ & 0.151 & $-0.238^{*}$ & 0.136 \\
\hline & $(0.123)$ & $(0.193)$ & (0.139) & $(0.164)$ \\
\hline \multirow[t]{2}{*}{ Father's educational level } & $0.038^{* *}$ & 0.036 & $0.043^{* * *}$ & 0.026 \\
\hline & $(0.015)$ & $(0.023)$ & $(0.017)$ & $(0.021)$ \\
\hline \multirow[t]{2}{*}{ Mother's educational level } & 0.023 & -0.011 & 0.027 & -0.004 \\
\hline & $(0.017)$ & $(0.024)$ & (0.019) & $(0.022)$ \\
\hline \multirow[t]{2}{*}{ Grandmother (mother's side) foreign } & -0.065 & $-0.948^{* * *}$ & -0.122 & $-0.907^{* * *}$ \\
\hline & $(0.163)$ & $(0.280)$ & $(0.190)$ & $(0.271)$ \\
\hline \multicolumn{5}{|l|}{ Year of birth } \\
\hline \multirow[t]{2}{*}{1978} & 0.031 & -0.044 & 0.012 & -0.077 \\
\hline & $(0.081)$ & $(0.112)$ & $(0.100)$ & $(0.121)$ \\
\hline \multicolumn{5}{|l|}{1980 (ref.) } \\
\hline \multirow[t]{2}{*}{ Any internship during education } & $-0.157^{*}$ & 0.102 & -0.155 & 0.125 \\
\hline & $(0.090)$ & $(0.128)$ & $(0.103)$ & $(0.120)$ \\
\hline \multirow[t]{2}{*}{ Any student job during education } & $0.372^{* * *}$ & $0.352^{* *}$ & $0.422^{* * *}$ & $0.340^{* *}$ \\
\hline & $(0.113)$ & $(0.151)$ & $(0.132)$ & $(0.146)$ \\
\hline \multicolumn{5}{|l|}{ Start of job search: quarter in the year } \\
\hline \multirow[t]{2}{*}{ First quarter } & 0.149 & 0.085 & 0.139 & 0.040 \\
\hline & (0.139) & $(0.193)$ & $(0.158)$ & $(0.202)$ \\
\hline \multirow[t]{2}{*}{ Second quarter } & -0.142 & $-0.488^{* * *}$ & $-0.238 * *$ & $-0.480 * * *$ \\
\hline & (0.106) & $(0.142)$ & $(0.119)$ & $(0.142)$ \\
\hline \multicolumn{5}{|l|}{ Third quarter (ref.) } \\
\hline \multirow[t]{2}{*}{ Fourth quarter } & 0.131 & $0.398^{* *}$ & 0.214 & $0.398^{* *}$ \\
\hline & $(0.160)$ & $(0.192)$ & $(0.173)$ & $(0.183)$ \\
\hline \multirow[t]{2}{*}{ Months between leaving school and starting job search } & -0.014 & $-0.034^{* *}$ & -0.019 & $-0.034^{* *}$ \\
\hline & $(0.011)$ & $(0.016)$ & $(0.014)$ & $(0.016)$ \\
\hline \multirow[t]{2}{*}{ Youth unemployment rate } & -0.010 & 0.004 & -0.008 & 0.012 \\
\hline & $(0.013)$ & $(0.018)$ & $(0.014)$ & $(0.019)$ \\
\hline \multicolumn{5}{|l|}{ Duration dependence } \\
\hline \multicolumn{5}{|l|}{$t \in[0,1)$ (ref.) } \\
\hline \multirow[t]{2}{*}{$\mathrm{t} \in[1,2)$} & $-0.276^{* *}$ & 0.007 & -0.104 & 0.005 \\
\hline & $(0.136)$ & $(0.142)$ & $(0.136)$ & $(0.131)$ \\
\hline \multirow[t]{2}{*}{$t \in[2,3)$} & -0.164 & 0.218 & 0.206 & 0.243 \\
\hline & $(0.204)$ & $(0.259)$ & $(0.210)$ & $(0.235)$ \\
\hline \multirow[t]{2}{*}{$t \in[3,4)$} & -0.295 & $0.661^{*}$ & 0.254 & $0.683^{* *}$ \\
\hline & $(0.281)$ & $(0.390)$ & $(0.288)$ & $(0.328)$ \\
\hline$t \in[4,6)$ & $-0.714^{* *}$ & 0.366 & -0.053 & 0.337 \\
\hline & $(0.330)$ & $(0.548)$ & $(0.316)$ & $(0.426)$ \\
\hline$t \in[6,9)$ & $-0.555^{*}$ & $0.998^{*}$ & 0.154 & $0.898^{*}$ \\
\hline & $(0.335)$ & $(0.600)$ & $(0.317)$ & $(0.458)$ \\
\hline$t \in[9,18)$ & $-0.662^{* *}$ & $1.221^{* *}$ & 0.046 & $1.025^{* *}$ \\
\hline & $(0.322)$ & $(0.567)$ & (0.309) & $(0.489)$ \\
\hline
\end{tabular}




\begin{tabular}{|c|c|c|c|c|}
\hline$t>18$ & $\begin{array}{c}-0.881 * * * \\
(0.288)\end{array}$ & $\begin{array}{c}2.09 * * * \\
(0.790)\end{array}$ & $\begin{array}{l}-0.052 \\
(0.394)\end{array}$ & $\begin{array}{c}1.862^{* *} \\
(0.763)\end{array}$ \\
\hline \multicolumn{5}{|c|}{ Unobserved heterogeneity: estimates } \\
\hline $\begin{array}{l}\gamma_{2} \\
\gamma_{3}\end{array}$ & \multicolumn{2}{|c|}{$\begin{array}{c}1.633 \\
(0.377) \\
2.896 \\
(0.316)\end{array}$} & \multicolumn{2}{|c|}{$\begin{array}{c}1.551 \\
(0.335) \\
2.983 \\
(0.271)\end{array}$} \\
\hline$v_{2}$ & $\begin{array}{c}1.164 * * * \\
(0.409) \\
2.113^{* * *} \\
(0.446)\end{array}$ & $\begin{array}{c}4.163^{* * *} \\
(0.949) \\
6.785^{* * *} \\
(1.009)\end{array}$ & $\begin{array}{c}1.059 * * \\
(0.478) \\
2.969 * * * \\
(0.498)\end{array}$ & $\begin{array}{c}4.015^{* * *} \\
(0.977) \\
6.386^{* * *} \\
(1.039)\end{array}$ \\
\hline \multicolumn{5}{|c|}{ Unobserved heterogeneity: resulting probabilities and correlation coefficients } \\
\hline $\begin{array}{l}p_{1} \\
p_{2} \\
p_{3}\end{array}$ & & & & \\
\hline $\operatorname{cor}\left[\exp \left(v_{\mathrm{e}}\right), \exp \left(v_{\mathrm{o}}\right)\right]$ & \multicolumn{2}{|c|}{0.990} & \multicolumn{2}{|c|}{0.990} \\
\hline Log-likelihood & \multicolumn{2}{|c|}{-4606.553} & \multicolumn{2}{|c|}{-4594.661} \\
\hline AIC & \multicolumn{2}{|c|}{9347.107} & \multicolumn{2}{|c|}{9331.321} \\
\hline Parameters & \multicolumn{2}{|c|}{67} & \multicolumn{2}{|c|}{71} \\
\hline Observations & \multicolumn{2}{|c|}{1434} & \multicolumn{2}{|c|}{1434} \\
\hline
\end{tabular}

Table C-2: Main results - estimates in case of not controlling for unobserved heterogeneity

\begin{tabular}{|c|c|c|c|c|}
\hline & \multicolumn{2}{|c|}{$\begin{array}{l}\text { A. Constant treatment } \\
\text { effect model }\end{array}$} & \multicolumn{2}{|c|}{ B. Extended model } \\
\hline & $\boldsymbol{\theta}_{\mathrm{e}}$ & $\boldsymbol{\theta}_{\text {。 }}$ & $\boldsymbol{\theta}_{\mathrm{e}}$ & $\boldsymbol{\theta}_{\circ}$ \\
\hline \multicolumn{5}{|l|}{ Treatment effect } \\
\hline Constant: $\delta_{0}$ & $\begin{array}{c}-2.099 * * * \\
(0.109)\end{array}$ & & $\begin{array}{c}-2.280 * * * \\
(0.139)\end{array}$ & \\
\hline Interaction with $\left(\mathrm{t}-\mathrm{t}_{0}\right): \delta_{1}$ & & & $\begin{array}{l}0.018^{*} \\
(0.011)\end{array}$ & \\
\hline Interaction with $\left(\mathrm{t}-\mathrm{t}_{0}\right)^{2}: \delta_{2} * 100$ & & & $\begin{array}{c}0.015 \\
(0.010)\end{array}$ & \\
\hline Interaction with $\mathrm{t}_{0}: \delta_{3}$ & & & $\begin{array}{c}0.022 \\
(0.034)\end{array}$ & \\
\hline Interaction with $\left(\mathrm{t}_{0}\right)^{2}: \delta_{4}$ & & & $\begin{array}{c}0.000 \\
(0.001)\end{array}$ & \\
\hline \multicolumn{5}{|l|}{ Explanatory variables } \\
\hline Constant & $\begin{array}{c}-1.330^{* * *} \\
(0.285)\end{array}$ & $\begin{array}{c}-1.238^{* * *} \\
(0.297)\end{array}$ & $\begin{array}{c}-1.325^{* * *} \\
(0.286)\end{array}$ & $\begin{array}{r}-1.238^{* * *} \\
(0.297)\end{array}$ \\
\hline Highest attained level of educati & & & & \\
\hline
\end{tabular}




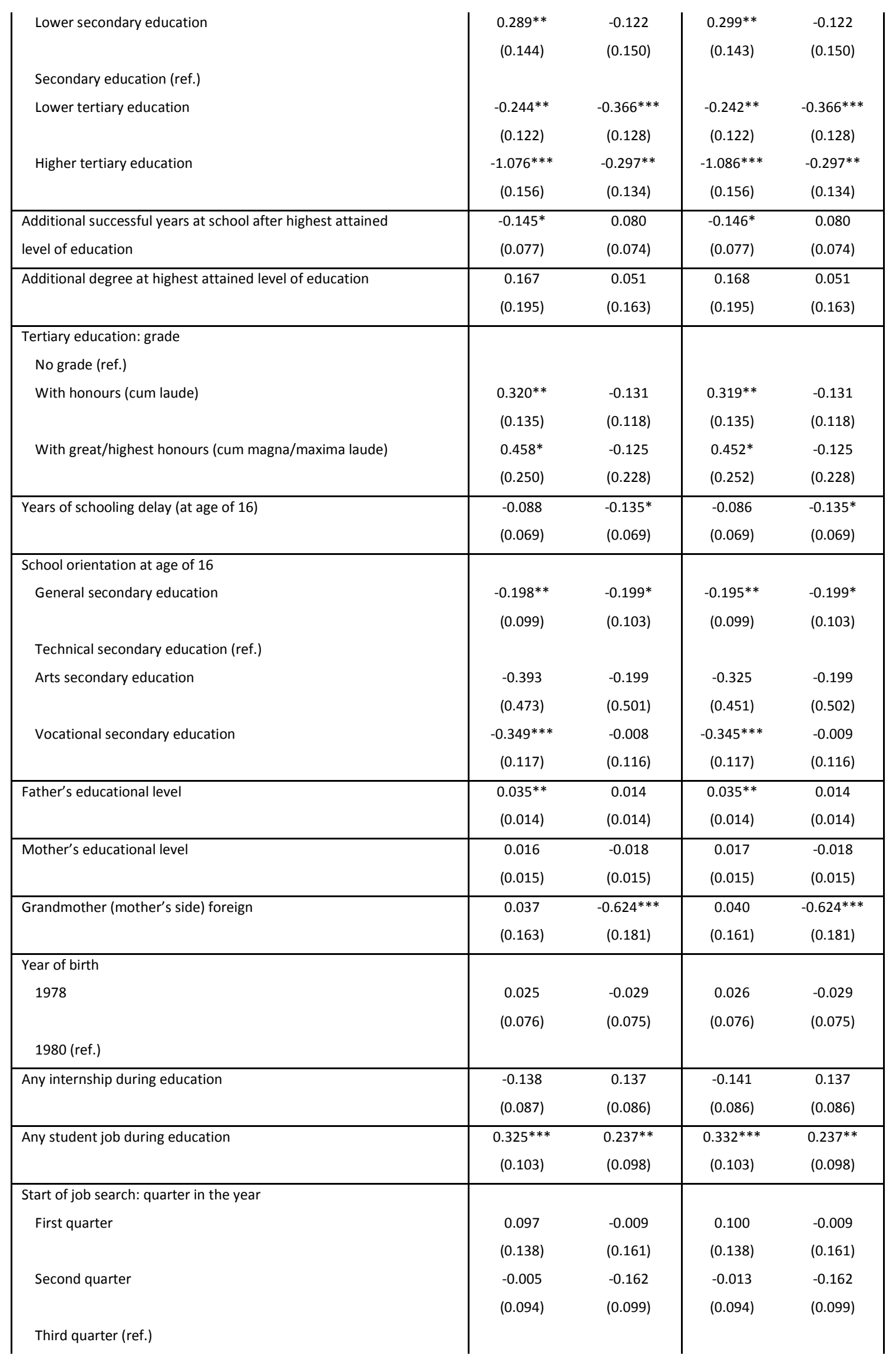




\begin{tabular}{|c|c|c|c|c|}
\hline Fourth quarter & $\begin{array}{l}0.099 \\
(0.146)\end{array}$ & $\begin{array}{l}0.231 * \\
(0.138)\end{array}$ & $\begin{array}{c}0.097 \\
(0.147)\end{array}$ & $\begin{array}{l}0.231 * \\
(0.138)\end{array}$ \\
\hline Months between leaving school and starting job search & $\begin{array}{l}-0.009 \\
(0.011)\end{array}$ & $\begin{array}{l}-0.020 \\
(0.013)\end{array}$ & $\begin{array}{l}-0.009 \\
(0.011)\end{array}$ & $\begin{array}{l}-0.020 \\
(0.013)\end{array}$ \\
\hline Youth unemployment rate & $\begin{array}{l}-0.004 \\
(0.012)\end{array}$ & $\begin{array}{l}0.025^{*} \\
(0.013)\end{array}$ & $\begin{array}{l}-0.004 \\
(0.012)\end{array}$ & $\begin{array}{l}0.025^{*} \\
(0.013)\end{array}$ \\
\hline Duration dependence & & & & \\
\hline $\mathrm{t} \in[0,1)$ (ref.) & & & & \\
\hline$t \in[1,2)$ & $\begin{array}{c}-0.523^{* * *} \\
(0.117)\end{array}$ & $\begin{array}{c}-0.451 * * * \\
(0.099)\end{array}$ & $\begin{array}{c}-0.512^{* * *} \\
(0.117)\end{array}$ & $\begin{array}{c}-0.451^{* * *} \\
(0.099)\end{array}$ \\
\hline$t \in[2,3)$ & $\begin{array}{c}-0.621^{* * *} \\
(0.141)\end{array}$ & $\begin{array}{c}-0.680 * * * \\
(0.128)\end{array}$ & $\begin{array}{c}-0.604^{* * *} \\
(0.141)\end{array}$ & $\begin{array}{c}-0.681^{* * *} \\
(0.128)\end{array}$ \\
\hline$t \in[3,4)$ & $\begin{array}{c}-0.932 * * * \\
(0.182)\end{array}$ & $\begin{array}{c}-0.717^{* * *} \\
(0.153)\end{array}$ & $\begin{array}{c}-0.911 * * * \\
(0.181)\end{array}$ & $\begin{array}{c}-0.717^{* * *} \\
(0.153)\end{array}$ \\
\hline$t \in[4,6)$ & $\begin{array}{c}-1.470 * * * \\
(0.186)\end{array}$ & $\begin{array}{c}-1.512^{* * *} \\
(0.182)\end{array}$ & $\begin{array}{c}-1.451 * * * \\
(0.186)\end{array}$ & $\begin{array}{c}-1.512^{* * *} \\
(0.182)\end{array}$ \\
\hline$t \in[6,9)$ & $\begin{array}{c}-1.415^{* * *} \\
(0.177)\end{array}$ & $\begin{array}{c}-1.359 * * * \\
(0.170)\end{array}$ & $\begin{array}{c}-1.407^{* * *} \\
(0.176)\end{array}$ & $\begin{array}{c}-1.359 * * * \\
(0.170)\end{array}$ \\
\hline$t \in[9,18)$ & $\begin{array}{c}-1.624^{* * *} \\
(0.151)\end{array}$ & $\begin{array}{c}-1.916^{* * *} \\
(0.203)\end{array}$ & $\begin{array}{c}-1.668^{* * *} \\
(0.155)\end{array}$ & $\begin{array}{c}-1.917^{* * *} \\
(0.203)\end{array}$ \\
\hline$t>18$ & $\begin{array}{c}-1.811^{* * *} \\
(0.137)\end{array}$ & $\begin{array}{c}-2.766 * * * \\
(0.375)\end{array}$ & $\begin{array}{c}-2.116^{* * *} \\
(0.233)\end{array}$ & $\begin{array}{c}-2.766 * * * \\
(0.375)\end{array}$ \\
\hline Log-likelihood & \multicolumn{2}{|c|}{-4640.855} & \multicolumn{2}{|c|}{-4638.876} \\
\hline AIC & \multicolumn{2}{|c|}{9403.709} & \multicolumn{2}{|c|}{9407.751} \\
\hline Parameters & \multicolumn{2}{|c|}{61} & \multicolumn{2}{|c|}{65} \\
\hline Observations & \multicolumn{2}{|c|}{1434} & \multicolumn{2}{|c|}{1434} \\
\hline
\end{tabular}




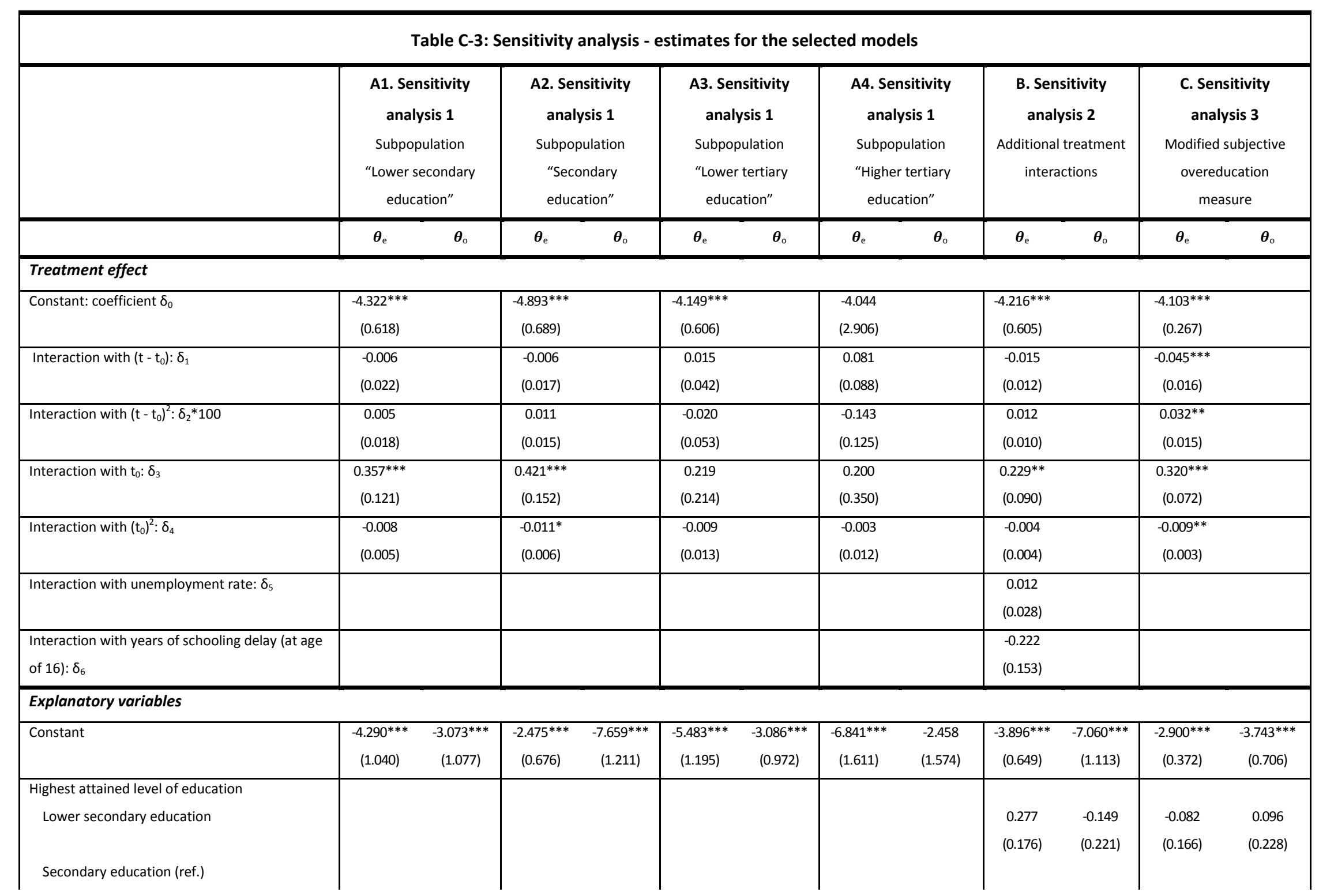

33 Overeducation at the start of the career - stepping stone or trap? 


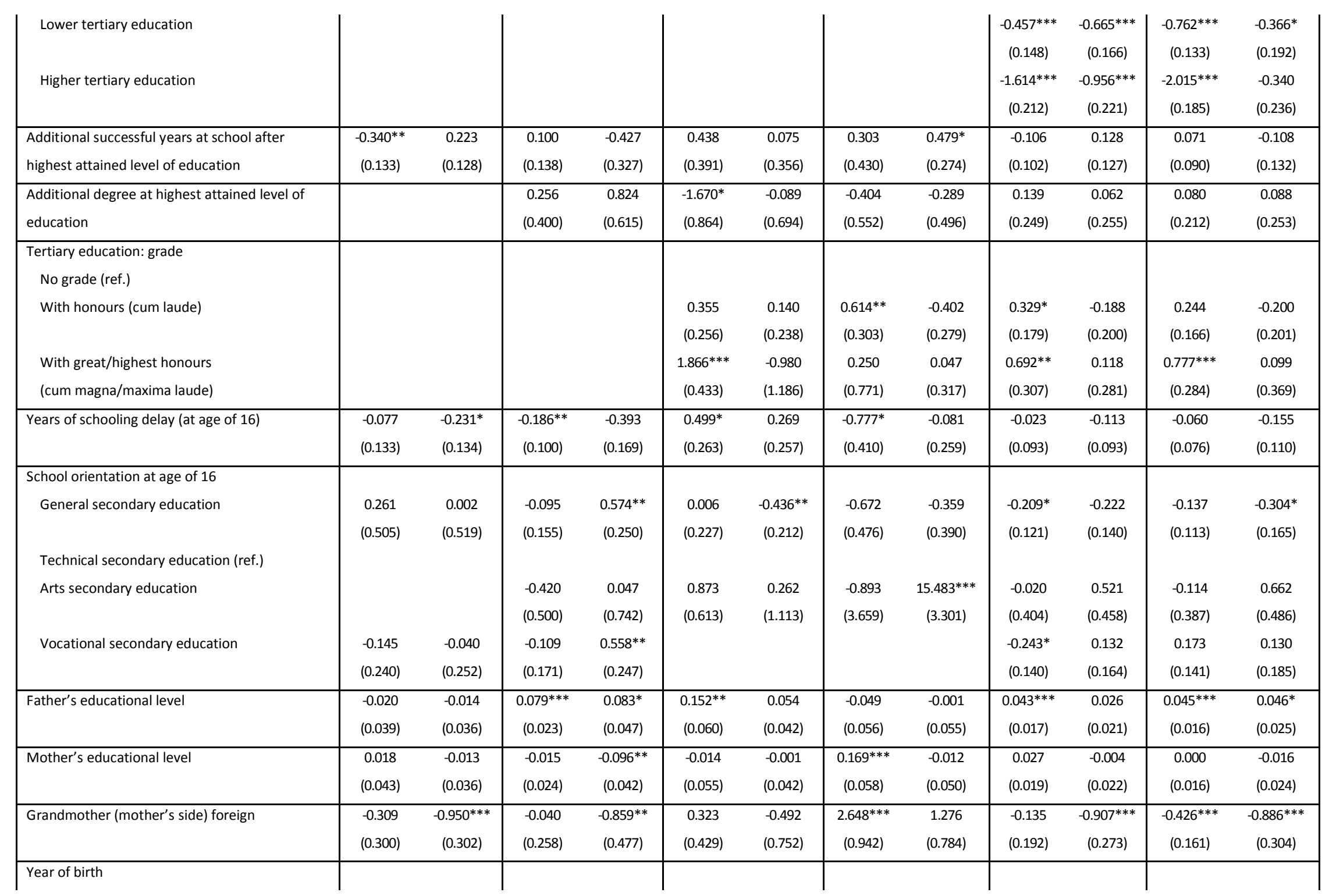

34 I Overeducation at the start of the career - stepping stone or trap? 


\begin{tabular}{|c|c|c|c|c|c|c|c|c|c|c|c|c|}
\hline $\begin{array}{l}1978 \\
1980 \text { (ref.) }\end{array}$ & $\begin{array}{l}-0.117 \\
(0.198)\end{array}$ & $\begin{array}{l}-0.027 \\
(0.179)\end{array}$ & $\begin{array}{c}0.024 \\
(0.122)\end{array}$ & $\begin{array}{c}0.164 \\
(0.196)\end{array}$ & $\begin{array}{c}0.383 \\
(0.269)\end{array}$ & $\begin{array}{c}0.137 \\
(0.267)\end{array}$ & $\begin{array}{c}0.936^{* *} \\
(0.391)\end{array}$ & $\begin{array}{c}-0.712 * * \\
(0.358)\end{array}$ & $\begin{array}{c}0.013 \\
(0.102)\end{array}$ & $\begin{array}{l}-0.077 \\
(0.123)\end{array}$ & $\begin{array}{l}-0.027 \\
(0.085)\end{array}$ & $\begin{array}{l}-0.014 \\
(0.119)\end{array}$ \\
\hline Any internship during education & $\begin{array}{l}-0.146 \\
(0.240)\end{array}$ & $\begin{array}{c}-0.034 \\
(0.211)\end{array}$ & $\begin{array}{l}-0.181 \\
(0.137)\end{array}$ & $\begin{array}{c}0.430 \\
(0.263)\end{array}$ & $\begin{array}{c}0.286 \\
(0.349)\end{array}$ & $\begin{array}{c}0.134 \\
(0.353)\end{array}$ & $\begin{array}{c}0.251 \\
(0.457)\end{array}$ & $\begin{array}{c}0.099 \\
(0.300)\end{array}$ & $\begin{array}{l}-0.158 \\
(0.103)\end{array}$ & $\begin{array}{c}0.125 \\
(0.119)\end{array}$ & $\begin{array}{c}-0.025 \\
(0.102)\end{array}$ & $\begin{array}{c}0.103 \\
(0.134)\end{array}$ \\
\hline Any student job during education & $\begin{array}{c}0.799 * * * \\
(0.245)\end{array}$ & $\begin{array}{l}0.503^{* *} \\
(0.227)\end{array}$ & $\begin{array}{c}0.246 \\
(0.171)\end{array}$ & $\begin{array}{c}0.096 \\
(0.243)\end{array}$ & $\begin{array}{l}1.256^{* *} \\
(0.597)\end{array}$ & $\begin{array}{c}0.511 \\
(0.319)\end{array}$ & $\begin{array}{c}1.017 \\
(0.625)\end{array}$ & $\begin{array}{c}0.956^{* *} \\
(0.472)\end{array}$ & $\begin{array}{c}0.420^{* * *} \\
(0.132)\end{array}$ & $\begin{array}{c}0.335^{* *} \\
(0.145)\end{array}$ & $\begin{array}{c}0.395^{* * *} \\
(0.116)\end{array}$ & $\begin{array}{c}0.442^{* * *} \\
(0.157)\end{array}$ \\
\hline $\begin{array}{l}\text { Start of job search: quarter in the year } \\
\text { First quarter }\end{array}$ & $\begin{array}{l}0.491 * \\
(0.280)\end{array}$ & $\begin{array}{l}-0.614 \\
(0.394)\end{array}$ & $\begin{array}{l}-0.014 \\
(0.190)\end{array}$ & $\begin{array}{c}0.373 \\
(0.309)\end{array}$ & $\begin{array}{l}0.710 \\
(0.605)\end{array}$ & $\begin{array}{l}-0.609 \\
(0.702)\end{array}$ & $\begin{array}{c}0.205 \\
(1.952)\end{array}$ & $\begin{array}{r}0.258 \\
(1.836)\end{array}$ & $\begin{array}{l}0.121 \\
(0.159)\end{array}$ & $\begin{array}{c}0.031 \\
(0.201)\end{array}$ & $\begin{array}{l}0.098 \\
(0.147)\end{array}$ & $\begin{array}{l}0.125 \\
(0.215)\end{array}$ \\
\hline Second quarter & $\begin{array}{l}0.597^{* *} \\
(0.246)\end{array}$ & $\begin{array}{c}0.283 \\
(0.245)\end{array}$ & $\begin{array}{l}-0.403 \\
(0.163)\end{array}$ & $\begin{array}{c}-0.782^{* *} \\
(0.311)\end{array}$ & $\begin{array}{c}-1.541^{* * *} \\
(0.344)\end{array}$ & $\begin{array}{c}-0.751^{* *} \\
(0.343)\end{array}$ & $\begin{array}{c}0.134 \\
(0.552)\end{array}$ & $\begin{array}{c}-0.929 * * * \\
(0.355)\end{array}$ & $\begin{array}{c}-0.244^{* *} \\
(0.121)\end{array}$ & $\begin{array}{c}-0.485^{* * *} \\
(0.142)\end{array}$ & $\begin{array}{c}-0.223^{* *} \\
(0.110)\end{array}$ & $\begin{array}{c}-0.798^{* * *} \\
(0.179)\end{array}$ \\
\hline $\begin{array}{l}\text { Third quarter (ref.) } \\
\text { Fourth quarter }\end{array}$ & $\begin{array}{c}1.067^{* *} \\
(0.451)\end{array}$ & $\begin{array}{c}0.056 \\
(0.360)\end{array}$ & $\begin{array}{c}0.105 \\
(0.236)\end{array}$ & $\begin{array}{c}1.245^{* * *} \\
(0.290)\end{array}$ & $\begin{array}{c}1.460^{* * *} \\
(0.470)\end{array}$ & $\begin{array}{c}0.689 * * \\
(0.301)\end{array}$ & $\begin{array}{l}-0.451 \\
(0.673)\end{array}$ & $\begin{array}{c}0.329 \\
(0.486)\end{array}$ & $\begin{array}{c}0.216 \\
(0.173)\end{array}$ & $\begin{array}{r}0.398^{* *} \\
(0.184)\end{array}$ & $\begin{array}{r}0.447^{* * *} \\
(0.150)\end{array}$ & $\begin{array}{c}0.548^{* * *} \\
(0.206)\end{array}$ \\
\hline $\begin{array}{l}\text { Months between leaving school and starting job } \\
\text { search }\end{array}$ & $\begin{array}{c}-0.039 * * \\
(0.019)\end{array}$ & $\begin{array}{l}-0.013 \\
(0.022)\end{array}$ & $\begin{array}{r}-0.003 \\
(0.015)\end{array}$ & $\begin{array}{r}-0.097 \\
(0.043)\end{array}$ & $\begin{array}{c}-0.496^{* * *} \\
(0.141)\end{array}$ & $\begin{array}{l}-0.088 \\
(0.088)\end{array}$ & $\begin{array}{r}-0.217 \\
(0.242)\end{array}$ & $\begin{array}{l}-0.097 \\
(0.143)\end{array}$ & $\begin{array}{r}-0.019 \\
(0.014)\end{array}$ & $\begin{array}{c}-0.034^{* *} \\
(0.016)\end{array}$ & $\begin{array}{l}-0.022^{*} \\
(0.012)\end{array}$ & $\begin{array}{c}-0.050^{* *} \\
(0.020)\end{array}$ \\
\hline Youth unemployment rate & $\begin{array}{c}0.051 \\
(0.028)\end{array}$ & $\begin{array}{c}0.055 \\
(0.036)\end{array}$ & $\begin{array}{l}-0.027 \\
(0.019)\end{array}$ & $\begin{array}{l}-0.002 \\
(0.032)\end{array}$ & $\begin{array}{c}-0.082^{* *} \\
(0.035)\end{array}$ & $\begin{array}{l}0.067^{*} \\
(0.039)\end{array}$ & $\begin{array}{c}0.056 \\
(0.068)\end{array}$ & $\begin{array}{c}-0.129 * * \\
(0.056)\end{array}$ & $\begin{array}{l}-0.013 \\
(0.019)\end{array}$ & $\begin{array}{c}0.011 \\
(0.019)\end{array}$ & $\begin{array}{c}0.013 \\
(0.013)\end{array}$ & $\begin{array}{c}0.005 \\
(0.021)\end{array}$ \\
\hline Duration dependence & & & & & & & & & & & & \\
\hline $\begin{array}{l}t \in[0,1) \text { (ref.) } \\
t \in[1,2)\end{array}$ & $\begin{array}{l}-0.187 \\
(0.268)\end{array}$ & $\begin{array}{l}-0.371 \\
(0.242)\end{array}$ & $\begin{array}{c}-0.532^{* * *} \\
(0.202)\end{array}$ & $\begin{array}{c}0.883^{* *} \\
(0.436)\end{array}$ & $\begin{array}{c}0.571^{* *} \\
(0.282)\end{array}$ & $\begin{array}{c}0.026 \\
(0.237)\end{array}$ & $\begin{array}{c}0.317 \\
(0.416)\end{array}$ & $\begin{array}{c}0.271 \\
(0.265)\end{array}$ & $\begin{array}{l}-0.099 \\
(0.137)\end{array}$ & $\begin{array}{c}0.006 \\
(0.130)\end{array}$ & $\begin{array}{l}-0.122 \\
(0.108)\end{array}$ & $\begin{array}{l}0.108 \\
(0.143)\end{array}$ \\
\hline $\mathrm{t} \in[2,3)$ & $\begin{array}{l}-0.535 \\
(0.386)\end{array}$ & $\begin{array}{l}-0.882 \\
(0.387)\end{array}$ & $\begin{array}{l}-0.055 \\
(0.280)\end{array}$ & $\begin{array}{c}1.688^{* * *} \\
(0.555)\end{array}$ & $\begin{array}{c}1.510^{* * *} \\
(0.322)\end{array}$ & $\begin{array}{l}-0.502 \\
(0.352)\end{array}$ & $\begin{array}{c}0.206 \\
(0.712)\end{array}$ & $\begin{array}{c}0.963 * * * \\
(0.284)\end{array}$ & $\begin{array}{c}0.217 \\
(0.215)\end{array}$ & $\begin{array}{c}0.246 \\
(0.233)\end{array}$ & $\begin{array}{c}0.314^{* *} \\
(0.159)\end{array}$ & $\begin{array}{c}0.195 \\
(0.223)\end{array}$ \\
\hline$t \in[3,4)$ & $\begin{array}{l}-0.311 \\
(0.453)\end{array}$ & $\begin{array}{l}-0.666 \\
(0.458)\end{array}$ & $\begin{array}{c}0.384 \\
(0.473)\end{array}$ & $\begin{array}{c}4.281^{* * *} \\
(1.300)\end{array}$ & $\begin{array}{c}1.130^{* *} \\
(0.482)\end{array}$ & $\begin{array}{l}-0.056 \\
(0.368)\end{array}$ & $\begin{array}{c}0.591 \\
(1.206)\end{array}$ & $\begin{array}{c}1.415^{* * *} \\
(0.370)\end{array}$ & $\begin{array}{c}0.273 \\
(0.296)\end{array}$ & $\begin{array}{c}0.689^{* *} \\
(0.322)\end{array}$ & $\begin{array}{l}0.384^{*} \\
(0.216)\end{array}$ & $\begin{array}{c}0.811^{* * *} \\
(0.289)\end{array}$ \\
\hline $\mathrm{t} \in[4,6)$ & $\begin{array}{l}-0.333 \\
(0.544)\end{array}$ & $\begin{array}{c}-1.293 * * \\
(0.633)\end{array}$ & $\begin{array}{l}-0.412 \\
(0.523)\end{array}$ & $\begin{array}{c}4.659 * * * \\
(1.200)\end{array}$ & $\begin{array}{c}1.079 * * \\
(0.525)\end{array}$ & $\begin{array}{l}-0.749 * \\
(0.448)\end{array}$ & $\begin{array}{c}0.638 \\
(2.072)\end{array}$ & $\begin{array}{c}1.908^{* *} \\
(0.824)\end{array}$ & $\begin{array}{l}-0.032 \\
(0.325)\end{array}$ & $\begin{array}{c}0.344 \\
(0.415)\end{array}$ & $\begin{array}{c}0.162 \\
(0.243)\end{array}$ & $\begin{array}{l}0.655 \\
(0.410)\end{array}$ \\
\hline$t \in[6,9)$ & $\begin{array}{c}0.005 \\
(0.539)\end{array}$ & $\begin{array}{l}-0.525 \\
(0.520)\end{array}$ & $\begin{array}{l}-0.383 \\
(0.482)\end{array}$ & $\begin{array}{c}4.869 * * * \\
(1.232)\end{array}$ & $\begin{array}{c}1.203^{* *} \\
(0.467)\end{array}$ & $\begin{array}{c}-1.725^{* *} \\
(0.735)\end{array}$ & $\begin{array}{c}1.106 \\
(2.354)\end{array}$ & $\begin{array}{c}3.116^{* * *} \\
(0.900)\end{array}$ & $\begin{array}{c}0.178 \\
(0.328)\end{array}$ & $\begin{array}{c}0.903^{* *} \\
(0.444)\end{array}$ & $\begin{array}{c}0.562^{* *} \\
(0.231)\end{array}$ & $\begin{array}{c}0.996^{* *} \\
(0.481)\end{array}$ \\
\hline
\end{tabular}




\begin{tabular}{|c|c|c|c|c|c|c|c|c|c|c|c|c|}
\hline \multirow[t]{2}{*}{$t \in[9,18)$} & $\begin{array}{l}-0.406 \\
(0.616)\end{array}$ & $\begin{array}{l}-1.345^{*} \\
(0.768)\end{array}$ & $\begin{array}{l}-0.161 \\
(0.447)\end{array}$ & $\begin{array}{c}4.819^{* * *} \\
(1.207)\end{array}$ & $\begin{array}{c}1.403^{* *} \\
(577)\end{array}$ & $\begin{array}{c}-1.264^{* * *} \\
(0.467)\end{array}$ & $\begin{array}{l}-0.041 \\
(2.768)\end{array}$ & $\begin{array}{l}2.620^{* *} \\
(1.049)\end{array}$ & $\begin{array}{c}0.072 \\
(0.315)\end{array}$ & $\begin{array}{c}1.025^{* *} \\
(0.477)\end{array}$ & $\begin{array}{l}0.437^{*} \\
(0.265)\end{array}$ & $\begin{array}{c}1.487^{* * *} \\
(0.533)\end{array}$ \\
\hline & $\begin{array}{l}-0.493 \\
(0.716)\end{array}$ & $\begin{array}{c}-1.759^{* *} \\
(0.737)\end{array}$ & $\begin{array}{l}-0.645 \\
(0.591)\end{array}$ & $\begin{array}{c}3.727^{* * *} \\
(1.398)\end{array}$ & $\begin{array}{c}1.822^{* *} \\
(0.781)\end{array}$ & 26 & $\begin{array}{l}-0.196 \\
(3.143)\end{array}$ & $\begin{array}{c}4.830 * * * \\
(1.200)\end{array}$ & $\begin{array}{l}-0.019 \\
(0.398)\end{array}$ & $\begin{array}{c}1.852^{* *} \\
(0.758)\end{array}$ & $\begin{array}{c}0.512 \\
(0.410)\end{array}$ & $\begin{array}{c}2.490 * * * \\
(0.755)\end{array}$ \\
\hline \multicolumn{13}{|c|}{ Unobserved heterogeneity: estimates } \\
\hline $\begin{array}{l}\gamma_{2} \\
\gamma_{3}\end{array}$ & \multicolumn{2}{|c|}{$\begin{array}{c}1.435 \\
(0.317)\end{array}$} & \multicolumn{2}{|c|}{$\begin{array}{c}1.259 \\
(0.188) \\
0.157 \\
(0.343)\end{array}$} & \multicolumn{2}{|c|}{$\begin{array}{c}0.782 \\
(0.223)\end{array}$} & \multicolumn{2}{|c|}{$\begin{array}{c}1.337 \\
(0.303) \\
-1.572 \\
(2.399)\end{array}$} & \multicolumn{2}{|c|}{$\begin{array}{c}1.559 \\
(0.336) \\
2.995 \\
(0.275)\end{array}$} & \multicolumn{2}{|c|}{$\begin{array}{c}1.599 \\
(0.176) \\
-1.107 \\
(0.365)\end{array}$} \\
\hline$v_{2}$ & $\begin{array}{c}2.594^{* * *} \\
(0.713)\end{array}$ & $\begin{array}{c}1.451^{* * *} \\
(0.537)\end{array}$ & $\begin{array}{c}2.213^{* * *} \\
(0.512) \\
3.203^{* * *} \\
(0.825)\end{array}$ & $\begin{array}{c}6.432^{* * *} \\
(1.029) \\
+\infty^{27}\end{array}$ & $\begin{array}{c}3.666^{* * *} \\
(0.558)\end{array}$ & $\begin{array}{l}-0.120 \\
(0.342)\end{array}$ & $\begin{array}{c}1.641 \\
(2.438) \\
0.987 \\
(3.803)\end{array}$ & $\begin{array}{c}3.639^{* * *} \\
(0.910) \\
-\infty^{28}\end{array}$ & $\begin{array}{c}1.081^{* *} \\
(0.466) \\
3.021^{* * *} \\
(0.499)\end{array}$ & $\begin{array}{c}4.024^{* * *} \\
(0.985) \\
6.403^{* * *} \\
(1.038)\end{array}$ & $\begin{array}{c}2.142^{* * *} \\
(0.211) \\
-1.334^{* * *} \\
(0.404)\end{array}$ & $\begin{array}{c}2.382^{* * *} \\
(0.488) \\
-\infty\end{array}$ \\
\hline \multicolumn{13}{|c|}{ Unobserved heterogeneity: resulting probabilities and correlation coefficients } \\
\hline $\begin{array}{l}\mathrm{p}_{1} \\
\mathrm{p}_{2} \\
\mathrm{p}_{3}\end{array}$ & \multicolumn{2}{|c|}{0.808} & & $\begin{array}{l}176 \\
19 \\
206\end{array}$ & \multicolumn{2}{|c|}{0.686} & & $\begin{array}{l}199 \\
759 \\
041\end{array}$ & $\begin{array}{l}0 . \\
0 . \\
0 .\end{array}$ & & & \\
\hline $\operatorname{cor}\left[\exp \left(v_{\mathrm{e}}\right), \exp \left(\mathrm{v}_{\mathrm{o}}\right)\right]$ & \multicolumn{2}{|c|}{1.000} & \multicolumn{2}{|c|}{0.918} & \multicolumn{2}{|c|}{-1.000} & \multicolumn{2}{|c|}{0.981} & \multicolumn{2}{|c|}{1.000} & \multicolumn{2}{|c|}{1.000} \\
\hline Log-likelihood & \multicolumn{2}{|c|}{-1024.419} & \multicolumn{2}{|c|}{-1978.052} & \multicolumn{2}{|c|}{-765.183} & \multicolumn{2}{|c|}{-670.047} & \multicolumn{2}{|c|}{-4593.340} & \multicolumn{2}{|c|}{-4058.329} \\
\hline AIC & \multicolumn{2}{|c|}{2156.839} & \multicolumn{2}{|c|}{4078.103} & \multicolumn{2}{|c|}{1648.365} & & 6.093 & 933 & 680 & 825 & \\
\hline Parameters & & & & 51 & & 99 & & 53 & & & & \\
\hline Observations & & & & 20 & & 44 & & 30 & & & & \\
\hline
\end{tabular}

\footnotetext{
${ }^{26}$ No inflow into a job for which one is overeducated in this time interval.

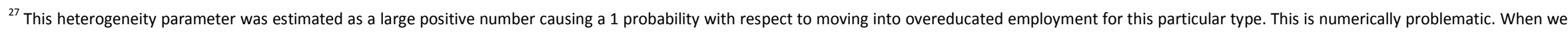
face this problem, in the spirit of Gaure et al. (2007), we mark the offending parameter as 'positive infinity' and keep it out of further estimation.

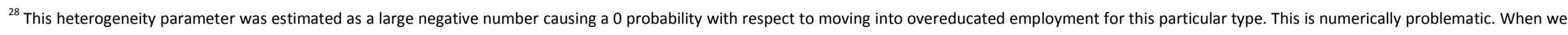
face this problem, in the spirit of Gaure et al. (2007), we mark the offending parameter as 'negative infinity' and keep it out of further estimation.
} 


\section{Appendix D: Additional figures}

Figure D-1: Kaplan-Meier estimates: survival in unemployment until entry in a first job (modified selfassessment method)

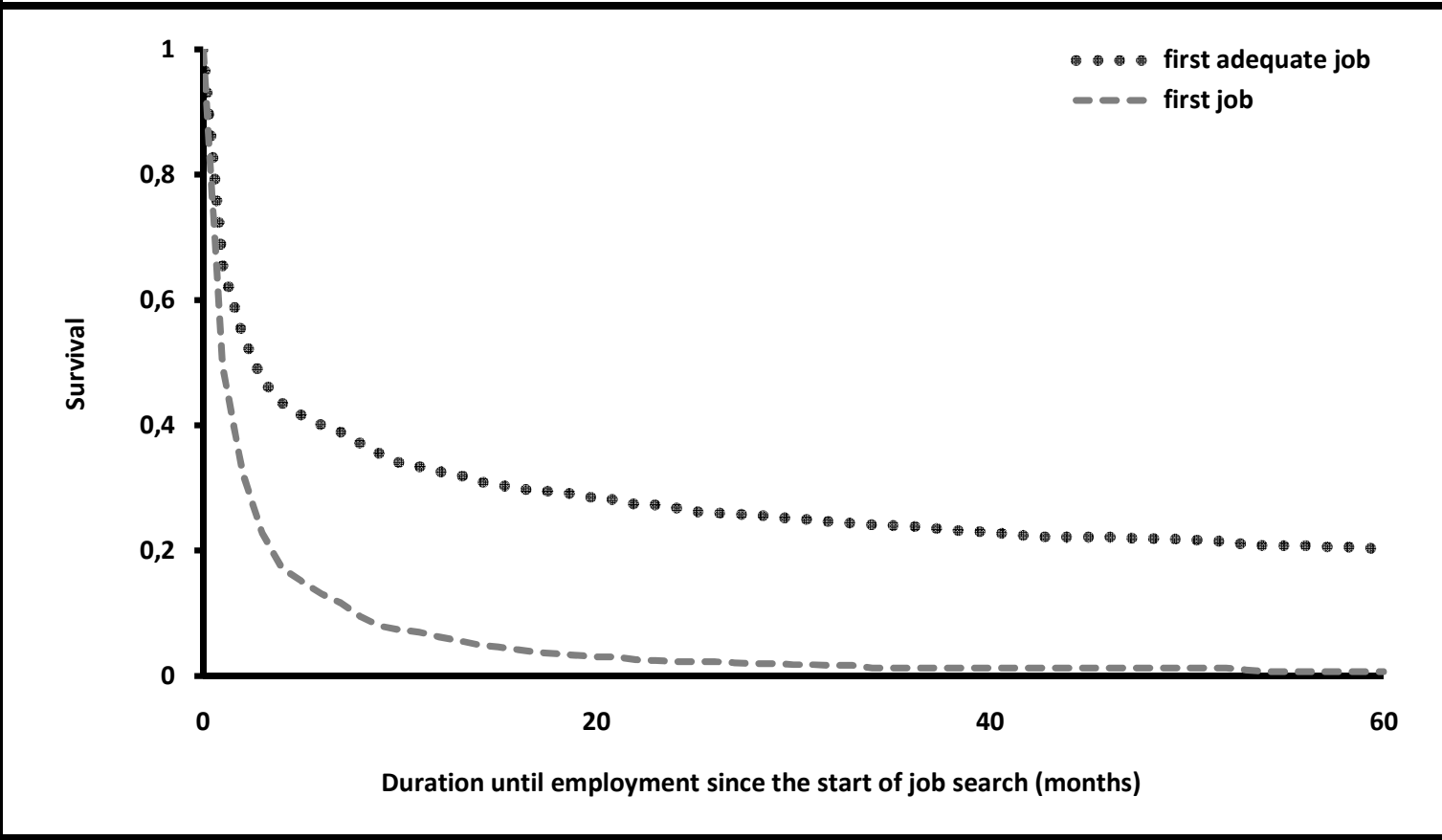




\section{References}

Abbring, J. H., and van den Berg, G. J. (2003), 'The non-parametric identification of treatment effects in duration models', Econometrica, 71, 1491-1517.

Albrecht, J., and Vroman, S. (2002), 'A matching model with endogenous skill requirements', International Economic Review, 43, 283-305.

Allen, J., and van der Velden, R. (2001), 'Educational mismatches versus skill mismatches: effects on wages, job satisfaction, and on-the-job search', Oxford Economic Papers, 5, 434-452.

Arulampalam, W. (2001), 'Is Unemployment Really Scarring? Effects of Unemployment Experiences on Wages,' Economic Journal, 111, 585-606.

Battu, H., Belfield, C., and Sloane, P. (1999), 'Overeducation among graduates: A cohort view', Education Economics, 7, 2138.

Bauer, T. (2002), 'Educational mismatch and wages: a panel analysis', Economics of Education Review, 21, 221-229.

Büchel, F., and Mertens, A. (2004), 'Overeducation, undereducation, and the theory of career mobility', Applied Economics, $36,803-816$

CBS (2001), Standaard Beroepenclassificatie 1992 - Editie 2001, Central Bureau of Statistics, Heerlen/Voorburg.

Chamberlain, G. (1980), 'Analysis of Covariance with Qualitative Data', Review of Economic Studies, 47, 225-238.

Chevalier, A. (2003), 'Measuring Over-education', Economica, 70, 509-531.

Cockx, B., Göbel, C., and Robin, S. (In press), 'Can Income Support for Part-Time Workers Serve as a Stepping Stone to Regular Jobs? An Application to Young Long-Term Unemployed Women', Empirical Economics, doi:10.1007/s00181010-0357-8.

de Grip, A., Bosma, H., Willems, D., and van Boxtel, M. (2008), 'Job-worker mismatch and cognitive decline', Oxford Economic Papers, 60, 237-253.

Dolado, J., Jansen, M., and Jimeno, J. (2009), 'On-the-job search in a matching model with heterogeneous jobs and workers', Economic Journal, 119, 200-228.

Dolton, P., and Vignoles, A, (2000), 'The incidence and effects of overeducation in the U.K. graduate labour market', Economics of Education Review, 19, 179-180.

Gaure, S., Roed, K., and Zhang, T. (2007), 'Time and causality: A Monte Carlo assessment of the timing-of-events approach', Journal of Econometrics, 141, 1159-1195.

Green, F., and Mclntosh, S. (2007), 'Is there a genuine under-utilization of skills among the over-qualified?', Applied Economics, 39, 427-439.

Groot, W., and Maassen van den Brink, H. (2000), 'Overeducation in the labor market: a meta-analysis', Economics of Education Review, 19, 149-158. 
Hartog, J. (2000), 'Overeducation and earnings: where are we, where should we go?', Economics of Education Review, 19, 131-147.

Heckman, J. J., and Singer, B. (1984), 'A Method for Minimizing the Impact of Distributional Assumptions in Econometric Models for Duration Data', Econometrica, 52, 271-320.

Lancaster, T. (1990), The Econometric Analysis of Transition Data, Cambridge University Press, Cambridge.

Leuven, E., and Oosterbeek, H. (2011), 'Overeducation and Mismatch in the Labor Market', in Hanushek, E., Machin, S., and Woessman, L. (ed.), Handbook of the Economics of Education, 4, 283-326.

Mavromaras, K., and McGuinness, S. (In press), 'Overskilling Dynamics and Education Pathways', Economics of Education Review, doi:10.1016/j.econedurev.2012.02.006.

Mavromaras, K., McGuinness, S., O'Leary, N., Sloane, P., and Wei, Z. (2010), 'Job Mismatches and Labour Market Outcomes: Panel Evidence on Australian University Graduates', IZA Discussion Paper, 5083.

McCormick, B. (1990), 'A Theory of Signalling During Job Search, Employment Efficiency, and "Stigmatised" Jobs', Review of Economic Studies, 57, 299-313.

McGuinness, S. (2006), 'Overeducation in the labour market', Journal of Economic Surveys, 20, 387-418.

Pissarides, C. (1994), 'Search unemployment with on-the-Job search', Review of Economic Studies, 61, 457-475.

Pollmann-Schult, M., and Büchel, F. (2004), 'Career prospects of overeducated workers in West Germany', European Sociological Review, 20, 321-331.

Richardson, K., and van den Berg, G. J. (In press), 'Duration dependence versus unobserved heterogeneity in treatment effects: Swedish labor market training and the transition rate to employment', Journal of Applied Econometrics, doi: 10.1002/jae.2263.

Robst, J. (1995), 'Career Mobility, job match and overeducation', Eastern Economic Journal, 21, 539-550.

Rubb, S. (2003), 'Overeducation: a short or long run phenomenon for individuals?', Economics of Education Review, 22, 389394.

Sicherman, N. (1991), 'Overeducation in the Labor Market', Journal of Labor Economics, 9, 101-122.

Sicherman, N., and Galor, O. (1990), 'A Theory of Career Mobility', Journal of Political Economy, 98, 169-92.

Skott, P. (2006), 'Wage inequality and overeducation in a model with efficiency wages', Canadian Journal of Economics, 39, 94-123.

SONAR (2003), Hoe maken de jongeren de overgang van school naar werk? Basisrapportering Cohorte 1978 (eerste golf), Leuven: Steunpunt WAV.

SONAR (2005), Hoe maken de jongeren de overgang van school naar werk? Basisrapportering Cohorte 1980 (eerste golf), Leuven: Steunpunt WAV.

Tsang, M. (1987), 'The impact of underutilization of education on productivity: a case study of the U.S. Bell Companies', Economics of Education Review, 4, 93-104.

van den Berg, G. J. (2001), 'Duration models: Specification, identification, and multiple durations', in: Heckman J.J., and Leamer E. (eds) Handbook of econometrics, 5, North Holland, Amsterdam. 
van den Berg, G. J., Holm, A., and van Ours, J. C. (2002), 'Do stepping-stone jobs exist? Early career paths in the medical profession', Journal of Population Economics, 15, 647-665.

van der Meer, P. (2006), 'The validity of two education requirement measures', Economics of Education Review, 25, 211219.

van Smoorenburg, M., and van der Velden, R. (2000), 'The training of school-leavers, complementarity or substitution?', Economics of Education Review, 19, 207-217.

Verhaest, D., and Omey, E. (2009), 'Objective over-education and worker well-being: A shadow price approach', Journal of Economic Psychology, 30, 469-481.

Verhaest, D., and Omey, E. (2010), 'The determinants of overeducation: different measures, different outcomes?', International Journal of Manpower, 31, 608-625.

Verhaest, D., and Omey, E. (In press), 'The relationship between formal education and skill acquisition in young workers' first jobs', The Manchester School.

Verhaest, D., and van der Velden, R. (In press), 'Cross-country differences in graduate overeducation', European Sociological Review, doi:10.1093/esr/jcs044. 